\title{
Investigation of microstructure, mechanical and machinability properties of Mo-added steel produced by powder metallurgy method
}

\author{
Mehmet Akif Erden ${ }^{1}$ • Nafiz Yaşar ${ }^{2}$ - Mehmet Erdi Korkmaz ${ }^{3}$ Burak Ayvacı ${ }^{4} \cdot$ K Nimel Sworna Ross $^{5} \cdot$ Mozammel Mia $^{6}$
}

Received: 13 January 2021 / Accepted: 5 April 2021 / Published online: 15 April 2021

(C) The Author(s) 2021

\begin{abstract}
This study presents the impact of molybdenum (Mo) inclusion on microstructure, mechanical, and machinability behavior of steels manufactured with powder metallurgy (PM) approach. PM steel samples with different molybdenum ratios were pressed at 750-MPa pressing pressure and sintered in the atmosphere-controlled tube furnace at $1400^{\circ} \mathrm{C}$ for $1 \mathrm{~h}$. While particle size and distribution of phases of PM steels with different molybdenum ratios were determined by optical microscope, mechanical properties were determined by applying tensile test. The results were observed that $3 \%$ Mo weight-added steel displayed the maximum yield and tensile strength. In addition, the machinability properties of $3 \%$ Mo-added steel, which has the highest yield and tensile strength, were investigated. In this work, we researched the thrust force and surface roughness as machinability output, and drilling parameters on the output were determined by utilizing analysis of variance. Finally, SEM images were taken from the inner surfaces of the machined holes and the fractured surfaces from tensile test, and information about the machinability of this alloy produced with PM was presented. As a result, an increase in yield and tensile strength and a reduction in strain were identified with the increase in Mo content. Moreover, the coated cutting tools are better on the machining output than the uncoated cutting tools in terms of green environment. The most important factors on the Fz and Ra are the coating condition and the feed rate with $56.53 \%$ and $43.62 \%$ PCR, respectively.
\end{abstract}

Keywords Powder metallurgy $\cdot$ Mo alloyed steels $\cdot$ Microstructure-mechanical property relationship $\cdot$ Machinability

\section{Introduction}

The steels are sensitive to heat treatment. In addition to the chemical elements, the ideal hardness; physical, mechanical, and electrical properties; and corrosion and high resistance to heat can be achieved as an outcome of the applied heat treatments $[1,2]$. Alloy steels continue to develop with dayto-day innovations in steel classes such as structural steels, tool steels, cold-hot work steels, speed steels, spring steels, stainless steels, and heat-resistant steels. With every new research and innovations, alloy steels continue to meet the needs. The alloy steel is commonly employed in several

1 Department of Biomedical Engineering, Karabuk University, Karabük, Turkey

2 Yenice Vocational High School, Karabük University, Karabük, Turkey

3 Department of Mechanical Engineering, Karabük University, Karabük, Turkey

4 Department of Manufacturing Engineering, Karabük University, Karabük, Turkey

5 Department of Mechanical Engineering, Kings Engineering College, Chennai, India

6 Department of Mechanical Engineering, Imperial College London, Exhibition Road, South Kensington, London SW7 2AZ, UK 
sectors, namely, aircraft industry, auto industry, and structures (bridges, buildings) [3-6].

In unalloyed and low alloy steels, high alloy steels are used if the desired properties are not available or insufficient. In addition to increasing the mechanical strength at normal temperatures, this type of alloying aims to obtain some desired properties such as heat, scaling, corrosion resistance, temperature hardness, and non-magnetization. Molybdenum is used to counteract the temper brittleness tendency in low nickelchromium steels. The inclusion of around $0.3 \%$ molybdenum offers this. The impact strength of nickel and chromium steels with molybdenum added after tempering also increases significantly. It also increases the tensile and yield strength. Molybdenum possesses positive impact to avert grain development, increasing the hardening ability. It eliminates temper brittleness. During slow cooling from tempering temperature, carbide precipitation occurs at the grain boundaries of some alloys, which causes brittleness. Molybdenum eliminates this negative effect. Likewise, it rises the creep and wear resistance of molybdenum steels [7, 8].

Molybdenum applications have revealed the suitability of steel structures to work in knocking places. It is frequently preferred in aircraft and ground vehicle engines and manufacturing sector steels. Molybdenum can also be used as a flame-resistant coating for other metals. It was reported from Hossam et al. [9] that Mo in small amount increase the hardenability of steels when it was dissolved in austenite. Lee et al. [10] showed that molybdenum raised the impact of precipitation hardening in $\mathrm{Nb}$-added HSLA steels. Junhua et al. [11] researched the outcome of Mo constituent on the mechanical and microstructure properties of high strength pipeline steel X80. It was reasoned that the volume fractions of acicular ferrite raised as the measure of increase in Mo content, which brought about an addition in yield strength and rigidity.

PM is the process of breaking metal and alloy powders into pieces without melting them under certain pressure and temperature. The prepared powders are bonded to each other by diffusion through sintering heat treatment, increasing the strength of the material $[12,13]$. Despite the fact that the present steels are created as flat and tubular items, the making of forged steels has also accelerated in recent years. In addition, steel production is carried out by powder metallurgy method, although it is not sufficient today [14-16]. In the literature, there are some studies about PM steel production and microstructure mechanical property relationship. For example, Erden et al. [17] created V and Ti micro-alloyed steel with PM technique. They explored the sintering process by keeping it for $60 \mathrm{~min}$. at $1150^{\circ} \mathrm{C}$ and found that the yield and tensile properties increased as Ti and V ratio $(0.1-0.2 \%)$ increased. It can be attributed to the precipitation forming in particular $\mathrm{TiC}(\mathrm{N})$ and $\mathrm{VC}(\mathrm{N})$ during sintering and during cooling subsequent to sintering.
The elimination of machining is one of the ongoing goals of the PM industry. One of the major advantages of the PM process is that it requires very little secondary processing. Many parts are still used for close tolerance, better surface finish, and some post-production to create some geometric elements on the part which need secondary processing. PM market reviews have shown that around $60 \%$ of all parts require one of the machining operations [18]. Numerous parts have openings opposite to the pressing direction, narrow and long grooves, screw threads, etc. It requires additional machining operations to create geometric features and precise size and surface finish. With the widespread use of PM parts recently, more complex shapes are produced, which increases the need for secondary processing. PM parts have gained acceptability in recent years, as they increase the processing cost due to their poorer machinability and different machining difficulties compared to forged and cast parts [18]. This is due to the different material structure resulting from different production technique of PM materials. Therefore, when machining PM parts, it is initially performed with lower feeds and revolutions than forged materials of similar composition. Despite the poor machinability of PM materials, an advantage in processing is that the material that has to be removed in the form of chips is usually in smaller quantities than forged and bulk materials [19].

It is anticipated that the production of alloy steels will become even more important in the future, as small and complex parts, which are difficult to produce with conventional production methods, can be produced by powder metallurgy method. Although there are not enough studies in the literature on the machinability and development of steel materials produced by powder metallurgy method, there are a few studies. Since the machinability of PM steels is influenced by more variables than forged steels, their machining ability is less than wrought materials. For this reason, in the processing of PM steels, even for parts with similar chemical composition or mechanical properties with wrought steels, the processing conditions cannot be used exactly. In the machinability of PM workpieces, due to the porous structure, excessive tool wear often results in high cost and poor surface finish [18-20]. The processing of sintered compacts presents unique problems that are often not predetermined and whose examination is limited only by its quantity. The main factors affecting the machinability of PM products are given below: PM process characterization, material characterization, and machining parameters $[21,22]$. Although the machinability ability is low, some researchers have still examined the machinability of the materials produced by PM [19, 21, 23-26]. The common point in these studies is to perform machinability tests as well as to evaluate the performances of cutting tools for one PM material produced with a certain chemical composition without mechanical properties. These machining studies were also performed by either coated or uncoated 
cutting tools. In the path of filling the gap in research, in this work, the production of a new type steel in the desired composition was manufactured by adding different proportions of molybdenum powder into Fe powders. The particle size and distribution of the phases of the alloy steels produced were determined by optical microscope. The shape, distribution, and type of sediments were analyzed with the help of SEM and EDS. Tensile test and hardness test were applied to alloy steel samples with different chemical composition prepared in tensile sample sizes after microstructure analysis. The \% elongation, yield-tensile properties, and measured hardness values of the specimens are explained depending on the microstructural changes. The fracture type was determined by examining the fracture surface images obtained from the fractured tensile samples with the help of SEM. In addition, the machinability properties of $3 \%$ Mo-added steel, which has the highest mechanical properties among the manufactured samples, were investigated with coated and uncoated cutting tools.

\section{Materials and methods}

\subsection{Production of Mo-added PM steel}

The mechanical, microstructure, and machinability properties of $\mathrm{Fe}-\mathrm{C}$ and $\mathrm{Fe}-\mathrm{C}-\mathrm{Mo}$ alloy including various Mo ratios manufactured by PM were examined in this study. The dimensions of graphite, iron, niobium vanadium, and nickel powders used in the study are $<20 \mu \mathrm{m}, \leq 180 \mu \mathrm{m}$, and $<150 \mu \mathrm{m}$, and $96.5 \%, 99.9 \%$, and $99.9 \%$, respectively (Fig. 1).

Steel was produced by mixing in the chemical elements displayed in Table 1. The powders were evaluated in
Table 1 Chemical elements of PM steels

\begin{tabular}{llll}
\hline Alloys & Graphite $(\% \mathrm{wt})$ & $\mathrm{Mo}(\% \mathrm{wt})$ & $\mathrm{Fe}(\% \mathrm{wt})$ \\
\hline 0.55 graphite $+\mathrm{Fe}$ & 0.55 & - & Balanced \\
0.55 graphite $+\mathrm{Fe}+1 \mathrm{Mo}$ & 0.55 & 1 & Balanced \\
0.55 graphite $+\mathrm{Fe}+2 \mathrm{Mo}$ & 0.55 & 2 & Balanced \\
0.55 graphite $+\mathrm{Fe}+3 \mathrm{Mo}$ & 0.55 & 3 & Balanced \\
0.55 graphite $+\mathrm{Fe}+4 \mathrm{Mo}$ & 0.55 & 4 & Balanced \\
0.55 graphite $+\mathrm{Fe}+5 \mathrm{Mo}$ & 0.55 & 5 & Balanced \\
\hline
\end{tabular}

RADWAG AS-60-220 C/2 brand digital accurate scales with 0.0001 sensitivity at the rates given in Table 1 , before the mixing process. The weighed powders were mixed without balls for $1 \mathrm{~h}$ with a triaxial mixer of TURBULA T2F tool.

The mixed powders were made into blocks by unidirectional compression in a 100-ton capacity press (Hidroliksan, Konya, Turkey) at a pressing pressure of $750 \mathrm{MPa}$ in the form of a tensile sample in agreement with ASTM (E 8M) powder metal material standards. Sintering process is done to the sintering temperature of the samples at $5{ }^{\circ} \mathrm{C} / \mathrm{min}$ started with the rapid heating. After the temperature reaches the sintering temperature of $1400{ }^{\circ} \mathrm{C}$, the samples were remained at the temperature for one hour and transferred to room temperature by $5{ }^{\circ} \mathrm{C} / \mathrm{min}$ quickly cooled down and finally sintered. The manufacturing process of PM test samples is given in Fig. 2.

Sintered tensile samples are examined at $1 \mathrm{~mm} / \mathrm{min}$ in the SHIMADZU $(50 \mathrm{kN})$ tensile test setup. Flow stress graphs were achieved from each test. From these graphs, the yield strength $(0.2 \%)$, tensile strength, and strain values of the samples were measured and the variation in mechanical properties due to the change in the molybdenum ratio in the chemical
Fig. 1 SEM images of powders. a $\mathrm{Fe}(\leq 180 \mu \mathrm{m}, \times 2000)$. b Graphite $(<20 \mu \mathrm{m}, \times 2000)$. c Mo $(<150$ $\mu \mathrm{m}, \times 5000$ )
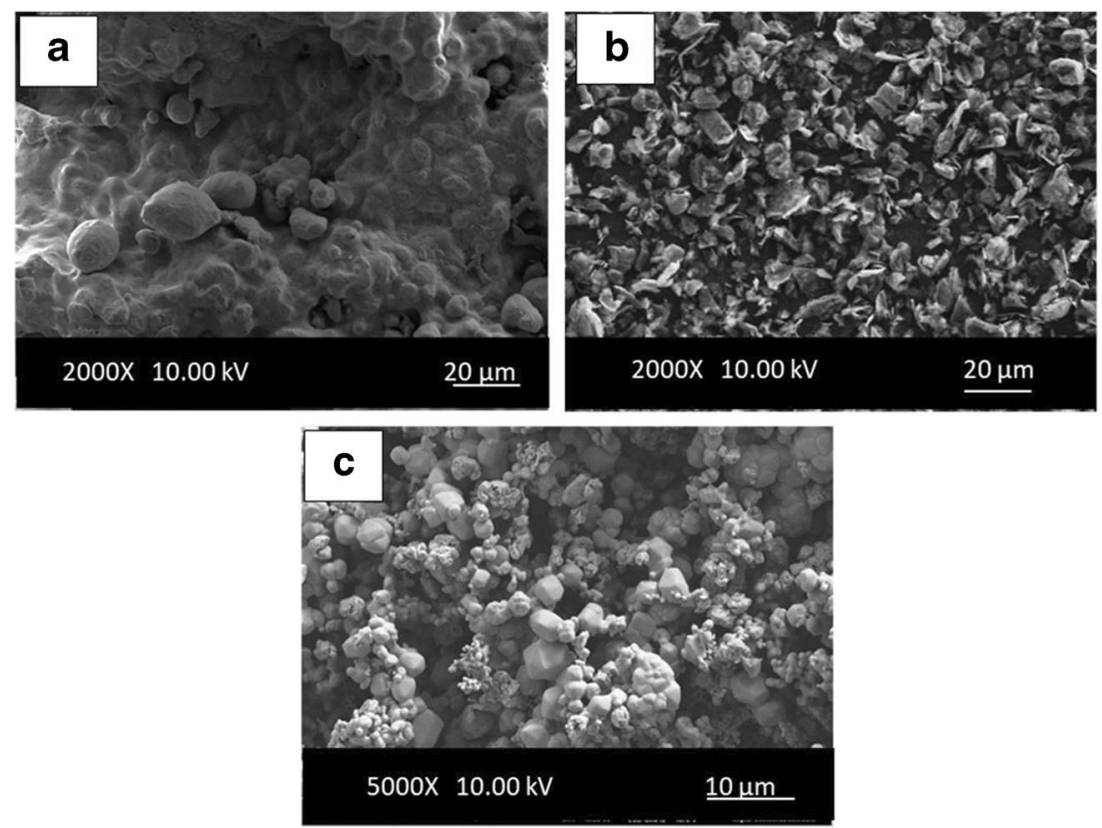


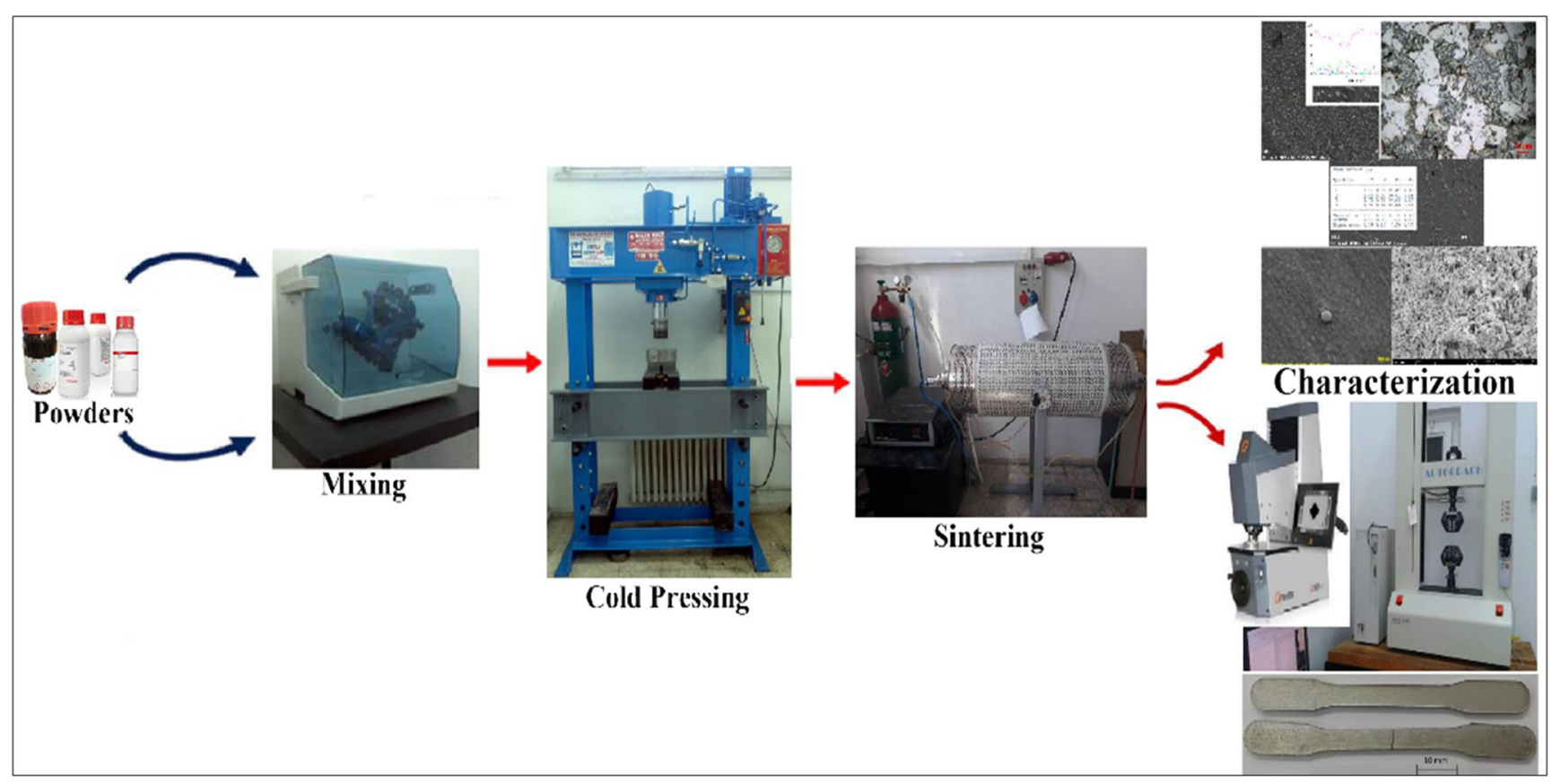

Fig. 2 Manufacturing process of powder metallurgy

composition was determined. Figure 3 presents the image of the tensile samples after pressing.

\subsection{Microstructural preparation}

Microstructural inspections were established with $\times 50-\times 1000$ magnification Nikon Epiphot 200 optical microscope using $2 \%$ nital solution by taking images of different sizes. Densities of the samples were made as specified by Archimets principle with Radwag density kit (Bruker Alpha, Bursa, Turkey) brand density measurement kit. Ferrite and pearlite ratios of powder metal steels were made using the metalographic point count technique described by Gladman and Woodhead [8]. Hardness measurements were applied for all samples of unalloyed and alloyed steel by applying HV0.5

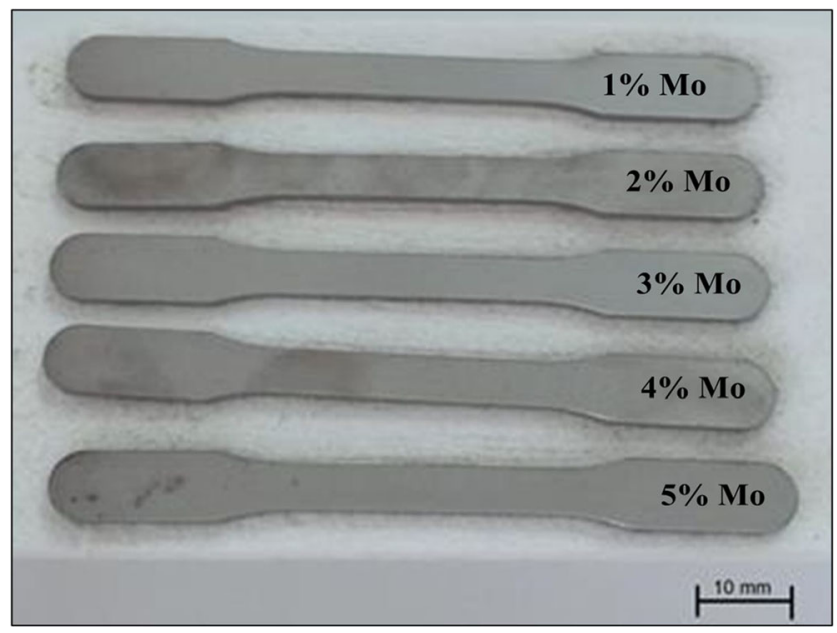

Fig. 3 Produced tensile test specimens
$(0.5 \mathrm{~kg})$ load in SHIMADZU hardness test setup. The hardness value was determined by taking the average of 5 hardness measurements from each sample. Spectral analysis studies were carried out with GNR Atlantis Optical Emission Spectrometer.

\subsection{Machinability process}

It has been employed to discover the elemental composition of alloyed PM steels produced in different chemical compositions. The chemical composition values aimed and obtained by this method were compared. According to the results, because the alloy with $0.55 \mathrm{Fe}-3 \mathrm{Mo}$ is the most durable, the machinability properties of this alloy were examined. Drilling process was chosen as the machining method and the cutting was explored with carbide drills (uncoated and coated). In the experiments, 3 different feeds and cutting speeds were used, and a total of 18 experiments were made, 9 tests for each tool. A fixed-point angle of 120 has been selected for coated and uncoated Carbide drills.

Drilling trials were performed in the Johnford VMC-550 machining center located in the laboratory of Gazi University, Faculty of Technology, Manufacturing Engineering Department (Fig. 4).

Uncoated and PVD-coated high-speed steel (HSS) drill bits with a 5-mm diameter which are used in the experiments were supplied from KYOCERA cutting tool company. The drills have a helix angle of $30^{\circ}$ and drill point angle of $120^{\circ}$. The factors for the experiment design were selected as the drill quality $(T)$, the cutting speed $(V)$, and the feed rate $(f)$ in the drilling of Mo alloyed steels. The process parameters' levels 
Fig. 4 The experimental setup for drilling tests

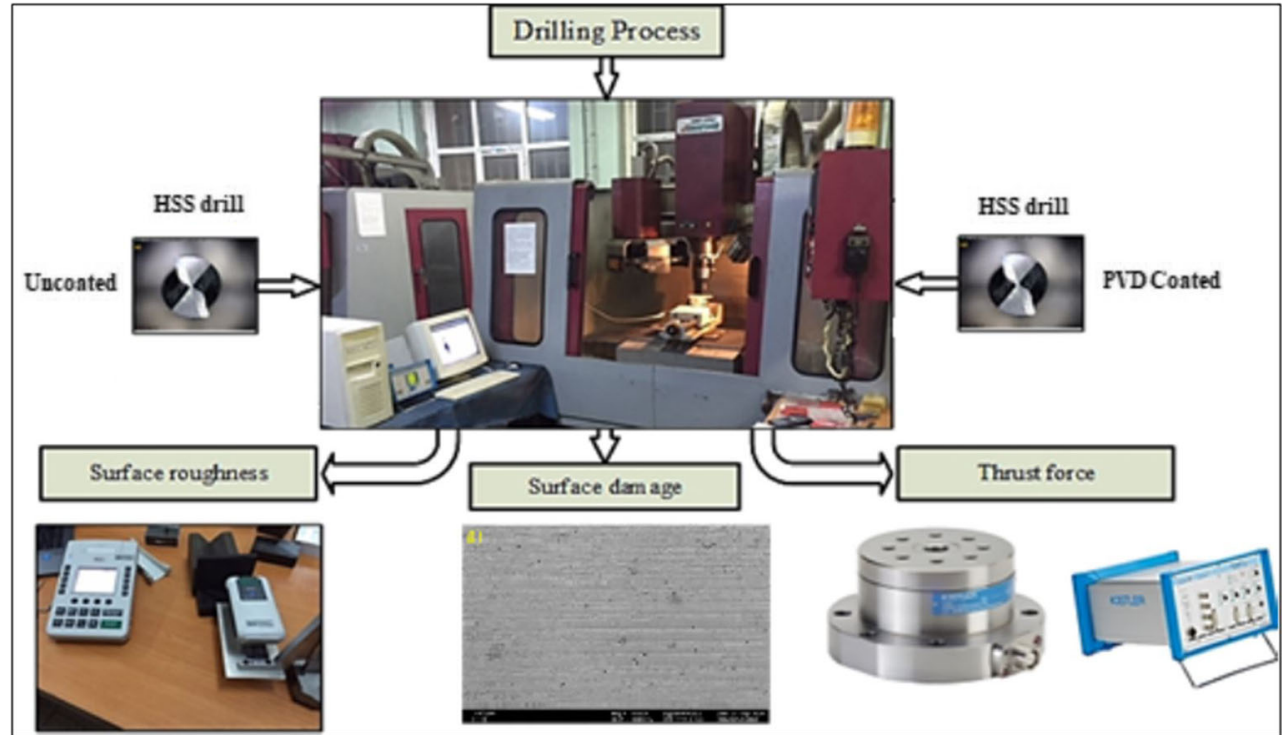

decided as taking into consideration of literature and machining sector are displayed in Table 2.

A clamping mold was designed and manufactured to carry out the experiments and to connect the samples to be drilled to the dynamometer. The measurements of shear forces and moments were carried out using Kistler 9257 A type dynamometer connected to the vertical machining center bench in the CNC machine tools. Experiments were done by taking the average value by repeating three times to obtain the best values. KISTLER 5070-A type amplifier (multi-channel) was employed to transfer signals from the four-axis piezoelectric dynamometer to the data reading card, which is used to obtain optimum results from the drilling tests, and KISTLER Dynoware software (2825A-02-01) was utilized to take the measurements.

The other purpose of this study is to evaluate the impact of cutting tools (uncoated HSS and PVD-coated HSS) and machining variables on the surface quality of the hole in the drilling process and to reveal the most suitable machining conditions. The roughness values of the experiments conducted within the scope of the study were calculated in the Marsurf M 300 type surface roughness device of "Mahr" brand. Probe suitable for hole diameter is used to make surface roughness measurements. Surface roughness data were evaluated by five different measurements for each hole and determined by taking their arithmetic mean. Measurements were taken at the same distance (hole center) for individual hole, corresponding to the hole axis. For each measurement, the part was rotated at an equal angle. Hole measurement distance is taken as $1.75 \mathrm{~mm}$. According to the drilling test results, the effect levels of the factors on the feed force $(\mathrm{Fz})$, torque $(T)$, and mean surface roughness $(\mathrm{Ra})$ were estimated by applying analysis of variance (ANOVA) at $95 \%$ confidence interval. Experimental design and analysis of variance were carried out with the help of Minitab17 package program. In addition, SEM images were taken from the inner surfaces of the machined holes and the fractured surfaces from tensile test, and a comment will be made on the machinability of this alloy produced with PM.

\section{Results and discussion}

\subsection{Microstructure and mechanical properties of Mo-added PM steel}

The microstructure analysis of sintered PM steels at $1400^{\circ} \mathrm{C}$ in argon atmosphere is given in Fig. 5. The images proved that the unalloyed PM steel is formed in ferrite and perlite phases. In addition, with the addition of Mo, it was observed that the
Table 2 Parameters and their levels for the drilling experiments

\begin{tabular}{lllll}
\hline Symbols & Parameters & 1st level & 2nd level & 3th level \\
\hline$M$ & Material & $0.55 \mathrm{C}$ 3Mo Fe & & \\
$T$ & Drill quality & HSS (uncoated) & HSS (TiAlN coated) & \\
$V$ & Cutting speed $(\mathrm{m} / \mathrm{min})$ & 15 & 20 & 25 \\
$f$ & Feed rate $(\mathrm{mm} / \mathrm{rev})$ & 0.05 & 0.1 & 0.15 \\
\hline
\end{tabular}


amount of perlite in the structure increased and with the addition of $2 \%$ Mo in weight, there were bainitic phases in the structure. In the addition of $4 \%$ and $5 \% \mathrm{Mo}$, a rise in number of pores and fall in the bainite phase was detected as a result of the excessive formation of $\mathrm{MoC}(\mathrm{N})$ deposits in the grain boundaries of Mo in the structure, and it is thought to affect the mechanical properties.

Though porosity is not good for strength [14-19], the current study got small and spherical pores which are not adversarial to the strength of the current material. As seen in Table 3, the theoretical density before sintering, density and porosity after sintering were calculated. It is observed that the amount of porosity generally increases when the powder increases with the alloy on the metal steels [27]. During sintering, the powder grains fused together. After sintering, the density of the samples naturally increased. The mechanical properties of components formed by PM are related to the pore ratio. While pores act as centers where stress is concentrated, they also contribute to crack propagation [28].

Tensile test results obtained from samples with different alloy ratios are shown in Fig. 6.

Additionally, the tensile strength and strain values of PM steel samples are displayed in Table 4.

As seen in Fig. 6 and Table 4, the tensile strength increased, and the elongation values decreased with the increase in the amount of molybdenum added to the Fegraphite main matrix composition. The change in mechanical behavior after the inclusion of Mo to unalloyed steel is summarized as follows. The tensile and yield strength increased by the addition of Mo to the material to a certain
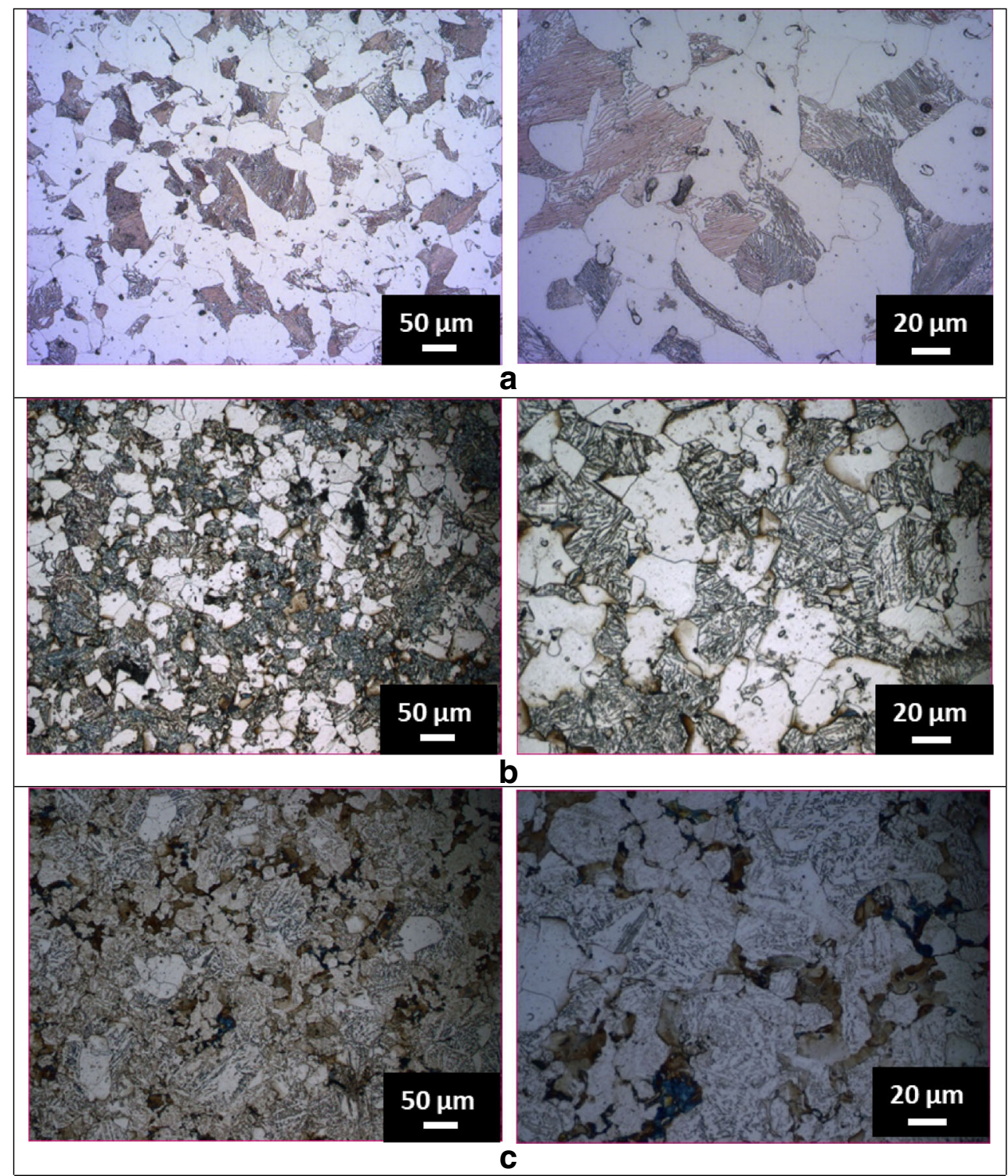

Fig. 5 Microstructure images of PM steels with distinct Mo ratios sintered in argon atmosphere at $1400^{\circ} \mathrm{C}(\times 200-\times 500)$. a Fe- 0.55 graphite. b Fe- 0.55 graphite-1Mo. c Fe-0.55 graphite-2Mo. d Fe-0.55 graphite-3Mo. e Fe- 0.55 graphite-4Mo. f Fe- 0.55 graphite-5Mo 

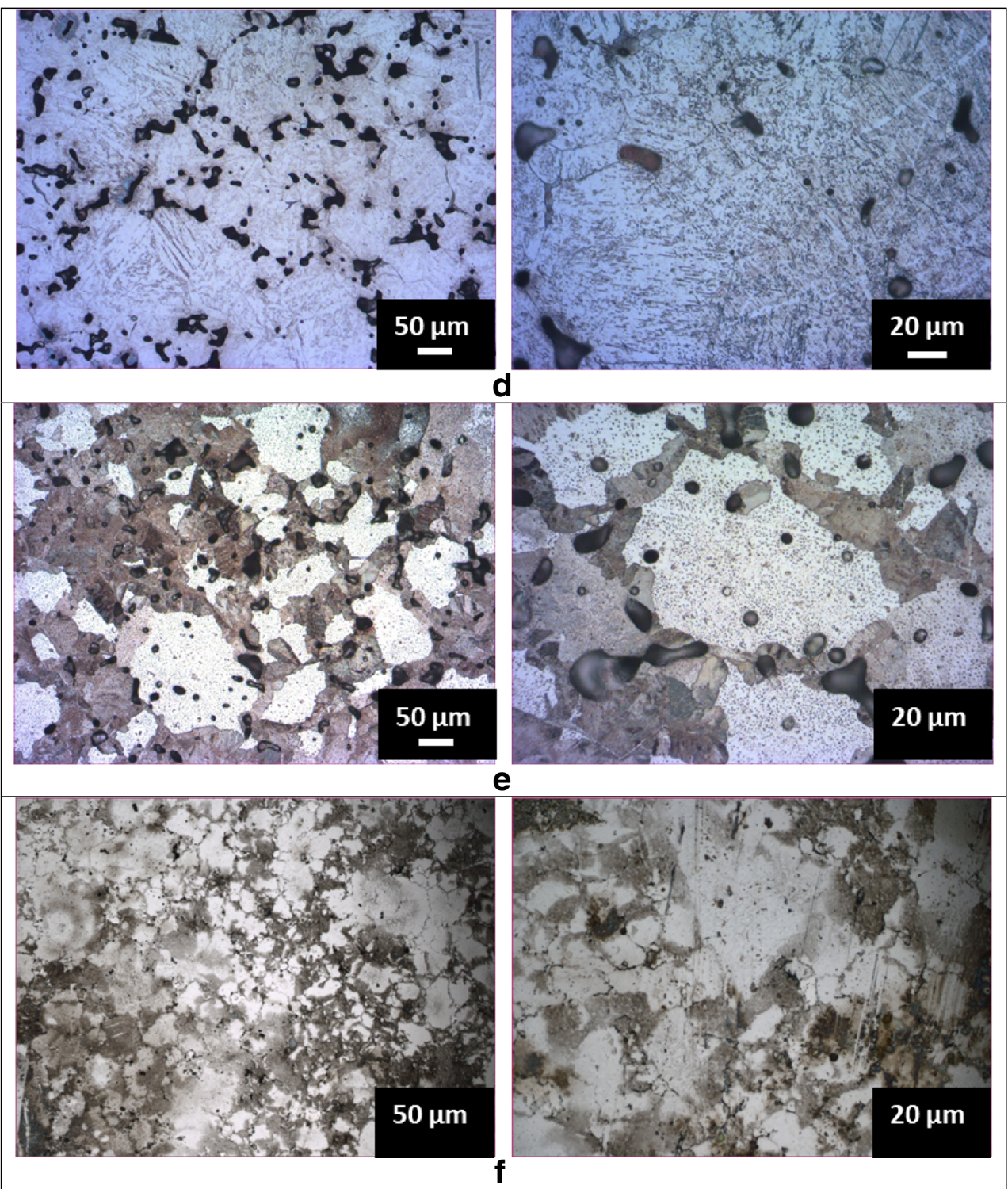

e

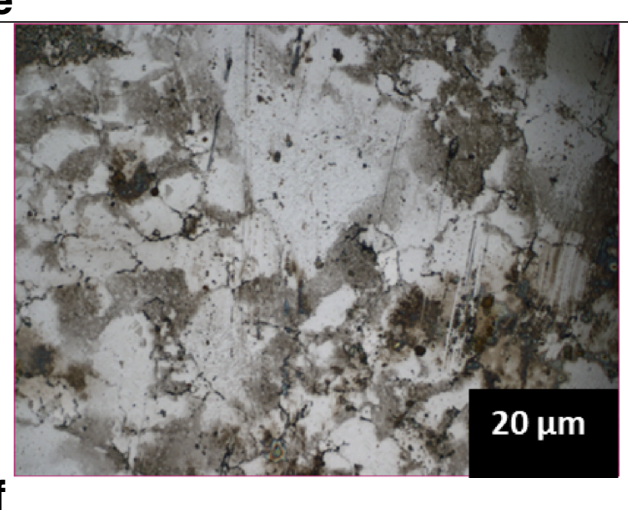

Fig. 5 (continued)

rate and caused it to decrease after a particular value. This event is clearly seen in Fig. 6. While an increase in strength was observed in the additions up to $3 \%$ molybdenum by weight, this increase started to decrease linearly. Up to $3 \%$ Mo by weight, the development of precipitates such as
$\mathrm{MoC}, \mathrm{MoN}$, and $\mathrm{MoC}(\mathrm{N})$ throughout and after sintering at the matrix and grain boundaries increased the strength by means of precipitation hardening, aggregation hardening, dispersion hardening, and grain size reduction strength enhancing mechanisms [29].

Table 3 Density and porosity in PM steels

\begin{tabular}{lllll}
\hline $\begin{array}{l}\text { Chemical composition } \\
0.55 \text { graphite }+\mathrm{Fe}\end{array}$ & $\begin{array}{l}\text { Theoretical density }\left(\mathrm{gr} / \mathrm{cm}^{3}\right) \\
7.8292\end{array}$ & $\begin{array}{l}\text { Post-sintered density }\left(\mathrm{gr} / \mathrm{cm}^{3}\right) \\
7.3714\end{array}$ & $\begin{array}{l}\text { Relative density }(\%) \\
94.15\end{array}$ & $\begin{array}{l}\text { Porosity }(\%) \\
5.85\end{array}$ \\
\hline 0.55 graphite $+\mathrm{Fe}+1 \mathrm{Mo}$ & 7.8536 & 7.3845 & 94.02 & 5.98 \\
0.55 graphite $+\mathrm{Fe}+2 \mathrm{Mo}$ & 7.8780 & 7.3575 & 93.39 & 6.61 \\
0.55 graphite $+\mathrm{Fe}+3 \mathrm{Mo}$ & 7.9024 & 7.3696 & 93.25 & 6.75 \\
0.55 graphite $+\mathrm{Fe}+4 \mathrm{Mo}$ & 7.9268 & 7.4176 & 93.57 & 6.43 \\
0.55 graphite $+\mathrm{Fe}+5 \mathrm{Mo}$ & 7.9512 & 7.3524 & 92.46 & 7.54 \\
\hline
\end{tabular}


Fig. 6 Difference of stress-strain curves of the unalloyed and alloyed PM steels with different Mo $(\mathbf{a}-0 \%$; $\mathbf{b}-1 \% ; \mathbf{c}-2 \%$; d- $3 \%$; e- $4 \%$; f- $5 \% \mathrm{Mo}$ )

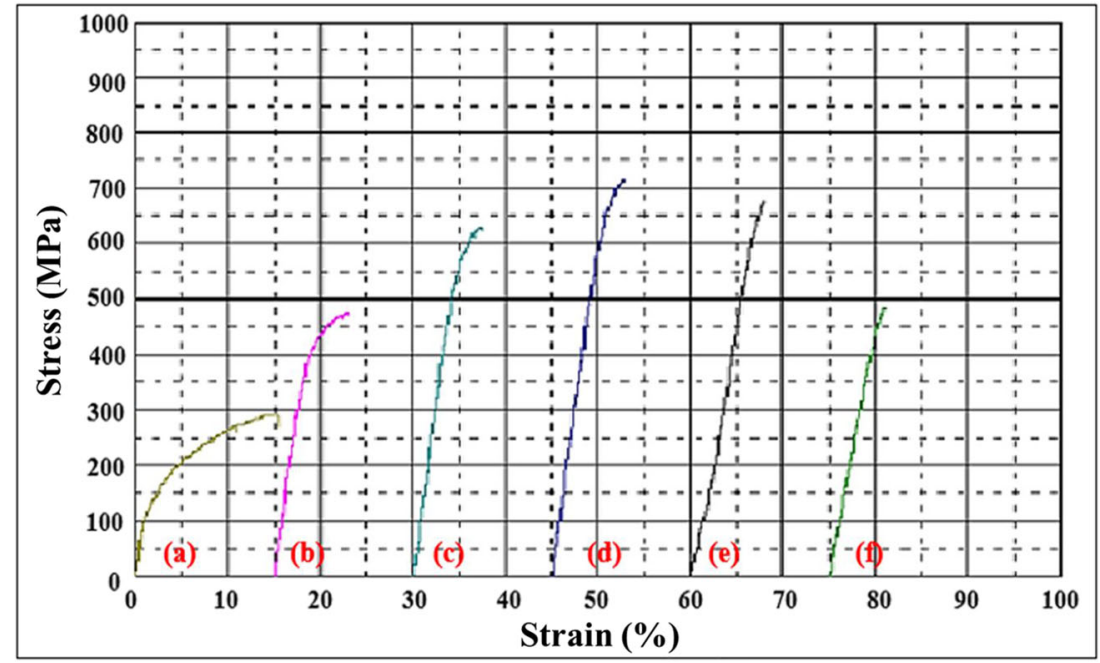

In addition, it was stated from Özdemirler et al. [5] that these precipitates caused an increase in strength by precipitation hardening, dispersion hardening, and grain size reduction mechanisms. Furthermore, the reason for the decrease in mechanical properties can be attributed to the addition of 4 and $5 \%$ Mo to unalloyed steel. It is seen that $\mathrm{MoC}(\mathrm{N})$ precipitates agglomerate excessively in the grain boundaries and the precipitates decrease the mechanical properties. As a matter of fact, Özdemirler et al. [5] observed in their study, the average particle dimensions increased a little with the increment of $\mathrm{NbC}$ ratio from 0.2 to $2 \%$ by weight. The reason for this was expressed as the excessive formation of large $\mathrm{NbC}$ deposits at the grain boundaries.

SEM microstructure and EDS analysis results of steel samples produced by PM method are shown in Fig. 7. The SEM microstructure in which $\mathrm{Fe}, \mathrm{C}$, and $\mathrm{Mo}$ are present in steel and carbide, nitride or carbonitride precipitates such as $\mathrm{MoC}(\mathrm{N})$ and $\mathrm{Fe} 3 \mathrm{C}$ have been determined as a result of EDS examinations. It has been reported that these precipitates limit the growth of austenite grain and also increase the strength of the material by precipitation hardening [30].

The effect of alloying elements in solution on recrystallization of austenite is not strong. The inhibition of grain boundary progression by precipitated particles is substantially more than the impact of dissolved atoms [31-34]. From the SEM,
EDS, and microstructure results, it was determined that the element Mo was present in solution and as a precipitated particle.

The EDS analysis results found in this study were compared with previous literatures; it shows that precipitates such as $\mathrm{MoC}(\mathrm{N})$ are formed in alloyed PM steels. In Fig. 7, it is found that $\mathrm{MoC}, \mathrm{MoN}$, and $\mathrm{MoCN}$ deposits are formed in the microstructure by adding Mo to unalloyed steel. SEM EDSs taken from the microstructure support this. As seen in Fig. 7, $\mathrm{C}$ amount in spectrum 1 taken from the precipitate is $3.12 \%$ by mass and Mo amount is 0.86 , while $\mathrm{C}$ amount in spectrum 2 taken from matrix is 2.97 , Mo amount is 0.65 . The increase in the amount of $\mathrm{C}$ and Mo in the spectrum no. 1 indicates that this precipitate is MoC. Likewise, similar studies support this finding [35]. After the tensile test of the PM steel sample sintered at $1400^{\circ} \mathrm{C}$, broken surface images were taken at $\times 250$ and $\times 1000$. When the SEM images of the alloy steel samples containing different Mo are examined (Fig. 8), the fractured surfaces displayed partially ductile (honeycomb structure) and partially brittle (separation planes) behavior. It was obviously observed that there are pores on all the broken surfaces. It can be attributed to the fracture occurred by the combination and advancement of micro spaces. Though, it is seen that the separation planes are an indicator of brittle fracture, which are most in alloy steels including 5\% Mo, medium
Table 4 Mechanical properties of sintered PM steels for $1 \mathrm{~h}$ at $1400^{\circ} \mathrm{C}$

\begin{tabular}{llll}
\hline Alloy & Ultimate tensile strength (MPa) & Elongation (\%) & Hardness (Hv 0.5) \\
\hline 0.55 graphite $+\mathrm{Fe}$ & 290 & 14 & 103 \\
0.55 graphite $+\mathrm{Fe}+1 \mathrm{Mo}$ & 479 & 8.9 & 121 \\
0.55 graphite $+\mathrm{Fe}+2 \mathrm{Mo}$ & 632 & 8.3 & 163 \\
0.55 graphite $+\mathrm{Fe}+3 \mathrm{Mo}$ & 718 & 8 & 241 \\
0.55 graphite $+\mathrm{Fe}+4 \mathrm{Mo}$ & 680 & 7.5 & 172 \\
0.55 graphite $+\mathrm{Fe}+5 \mathrm{Mo}$ & 485 & 6.3 & 128 \\
\hline
\end{tabular}


Fig. 7 SEM microstructure images of powder metal steels. a Unalloyed. b 3\% Mo steel $(\times 1000-\times 5000)$. c Spectrum 1 graph. d EDS results

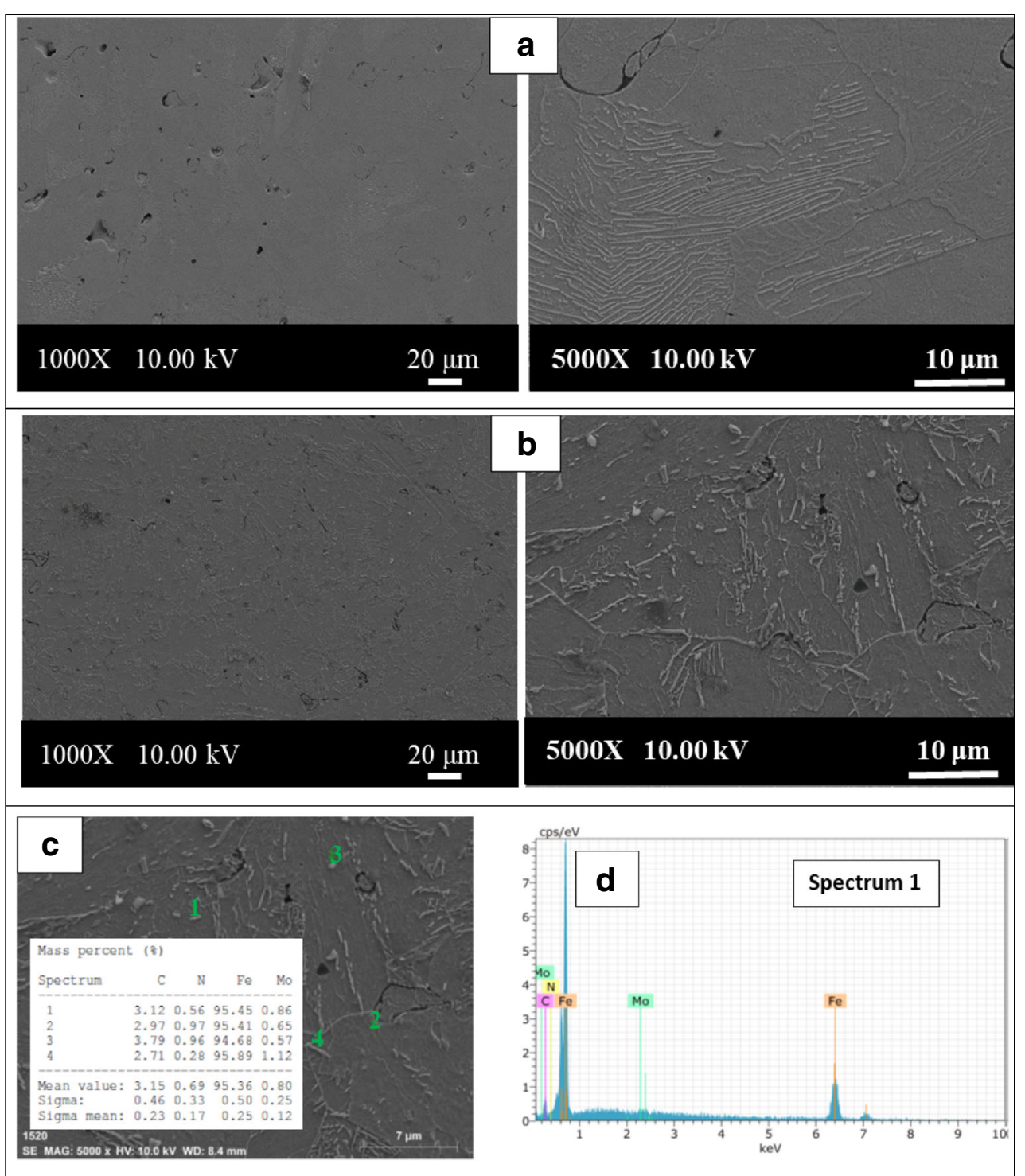

in alloy steels containing $3 \% \mathrm{Mo}$, and the least in alloy steels containing $1 \%$ Mo. Furthermore, the large voids were detected in the PM steels. The existence of the gaps reveals that the precipitates like $\mathrm{MoC}(\mathrm{N})$ detach from the surface during the tensile test [36]. Shanmugasundaram et al. [37] in their study observed that these larger voids were created on the examined surfaces of PM steels including $\mathrm{Cr}, \mathrm{Ni}$, and $\mathrm{Mo}$, and attributed this situation to the separation of carbide, nitride, and carbonitrides from the surface in the tensile tests. In consequence of the tensile tests, a rise in yield and tensile strength and a reduction in strain were detected with the increase in $\mathrm{Mo}, \mathrm{Cr}$, and Ni substance. The values obtained because of the tensile test show compatibility with the broken surface pictures.

Results from some samples are given in Table 5. Spectral analysis results show that the chemical composition planned before production and the chemical composition values obtained after production are compatible with each other.

\subsection{Machinability results of 3\% Mo-added PM steel}

Quite possibly the main cost factor in machining is energy utilization. The power consumed during machining is one of the elements that decide the energy utilization [38]. In drilling operations, high thrust forces negatively affect the hole quality and tool reliability, while unnecessary (insufficient) forces affect the productivity negatively. In addition, surface roughness in machining is immensely significant in terms of providing the desired surface quality in the final product. Correctly determined cutting tools, cutting parameters and cutting conditions have a noteworthy consequence on the desired surface quality $[39,40]$. In this investigation, the effects 
Fig. 8 Fractured surface picture of tensile samples with $1 \% \mathrm{Mo}(\mathrm{a}$ b), $3 \%$ Mo (c, d), and 5\% Mo (e, f) composition sintered at 1400

${ }^{\circ} \mathrm{C}(\mathbf{a}, \mathbf{c}, \mathbf{e} \times 250 ; \mathbf{b}, \mathbf{d}, \mathbf{f} \times 1000)$

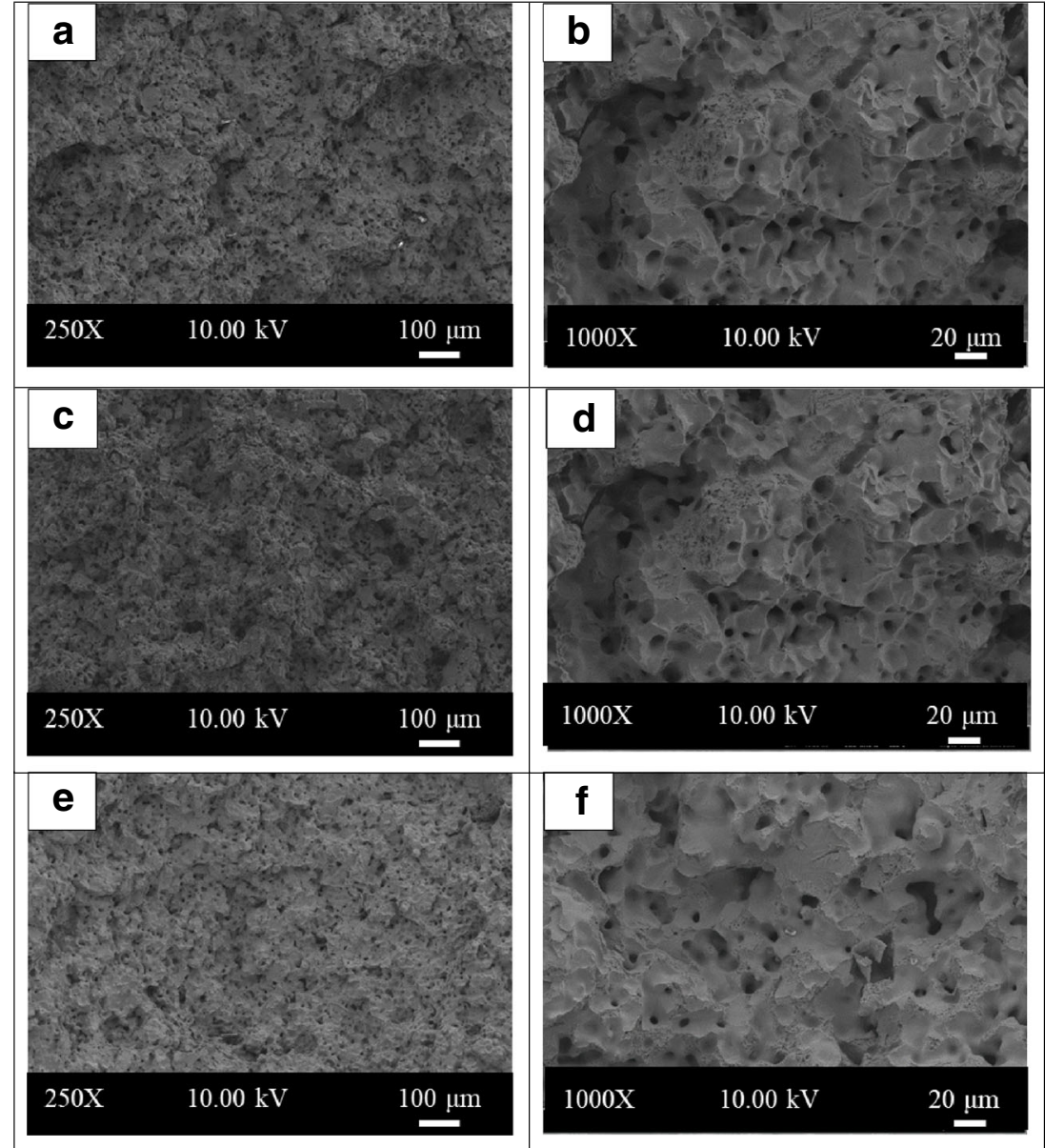

of these variables on the thrust force (Fz) and surface roughness ( $\mathrm{Ra})$, which are an important machinability output in terms of surface quality, were analyzed.

\subsubsection{Assessment of experimental thrust force}

Figure 9 presents the $\mathrm{Fz}$ changes obtained by using different cutting parameters with uncoated HSS carbide, and HSS PVD-coated cutting tools.

When the graphs are analyzed, it is seen that there is a decreasing trend in the thrust forces $(\mathrm{Fz})$ in both tools due to the increases in cutting speed at the feed rates of $0.05-0.15$ $\mathrm{mm} / \mathrm{rev}$. It can be said that this decrease on $\mathrm{Fz}$ with a rise in cutting speed is related to the reduction in the tool-chip contact region, and partly to the decrease in the yield strength of the material due to high heat with the increase in cutting speed [41, 42]. Considering all the levels of the feed rate, by increasing the speed from 15 to $20 \mathrm{~m} / \mathrm{min}$, the decrease rate for coated and uncoated tools was estimated as $4.5 \%$ and $11.2 \%$, respectively. This trend is $6.6 \%$ in the increase of the cutting speed from 20 to $25 \mathrm{~m} / \mathrm{min}$ in the feed rate of $0.05 \mathrm{~mm} / \mathrm{rev}$. However, in the same cutting speed increments, there is a slight increase in the feed rates from 0.1 to $0.15 \mathrm{~mm} / \mathrm{rev}$. These increases can be attributed to possible tool wear as a result of upsurge in heat at the cutting region and increased loads on the cutting tool at high speed-feed combination [43]. In addition, it is

Table 5 Spectral analysis results of cold PM steel samples sintered at $1400^{\circ} \mathrm{C}$

\begin{tabular}{|c|c|c|c|c|c|}
\hline \multicolumn{3}{|l|}{$\mathrm{Fe}-\mathrm{C}$} & \multicolumn{3}{|c|}{$\mathrm{Fe}-\mathrm{C}-3 \mathrm{Mo}$} \\
\hline Element & Result & Unit & Element & Result & Unit \\
\hline $\mathrm{C}$ & 0.35 & $\%$ wt & $\mathrm{C}$ & 0.33 & $\%$ wt \\
\hline $\mathrm{Si}$ & 0.005 & $\%$ wt & $\mathrm{Si}$ & 0.001 & $\%$ wt \\
\hline $\mathrm{Mn}$ & 0.164 & $\%$ wt & $\mathrm{Mn}$ & 0.189 & $\%$ wt \\
\hline $\mathrm{P}$ & 0.005 & $\%$ wt & $\mathrm{P}$ & 0.023 & $\%$ wt \\
\hline $\mathrm{Pb}$ & 0.001 & $\%$ wt & $\mathrm{Pb}$ & 0.006 & $\%$ wt \\
\hline $\mathrm{Cr}$ & 0.064 & $\%$ wt & $\mathrm{Cr}$ & 0.086 & $\%$ wt \\
\hline Mo & 0.011 & $\%$ wt & Mo & 2.88 & $\%$ wt \\
\hline $\mathrm{Ni}$ & 0.046 & $\%$ wt & $\mathrm{Ni}$ & 0.078 & $\%$ wt \\
\hline $\mathrm{Al}$ & 0.001 & $\%$ wt & $\mathrm{Al}$ & 0.0015 & $\%$ wt \\
\hline $\mathrm{Cu}$ & 0.095 & $\%$ wt & $\mathrm{Cu}$ & 0.098 & $\%$ wt \\
\hline $\mathrm{Co}$ & 0.008 & $\%$ wt & $\mathrm{Co}$ & 0.006 & $\%$ wt \\
\hline $\mathrm{S}$ & 0.003 & $\%$ wt & $\mathrm{S}$ & 0.003 & $\%$ wt \\
\hline $\mathrm{Fe}$ & Balanced & $\%$ wt & $\mathrm{Fe}$ & Balanced & $\%$ wt \\
\hline
\end{tabular}




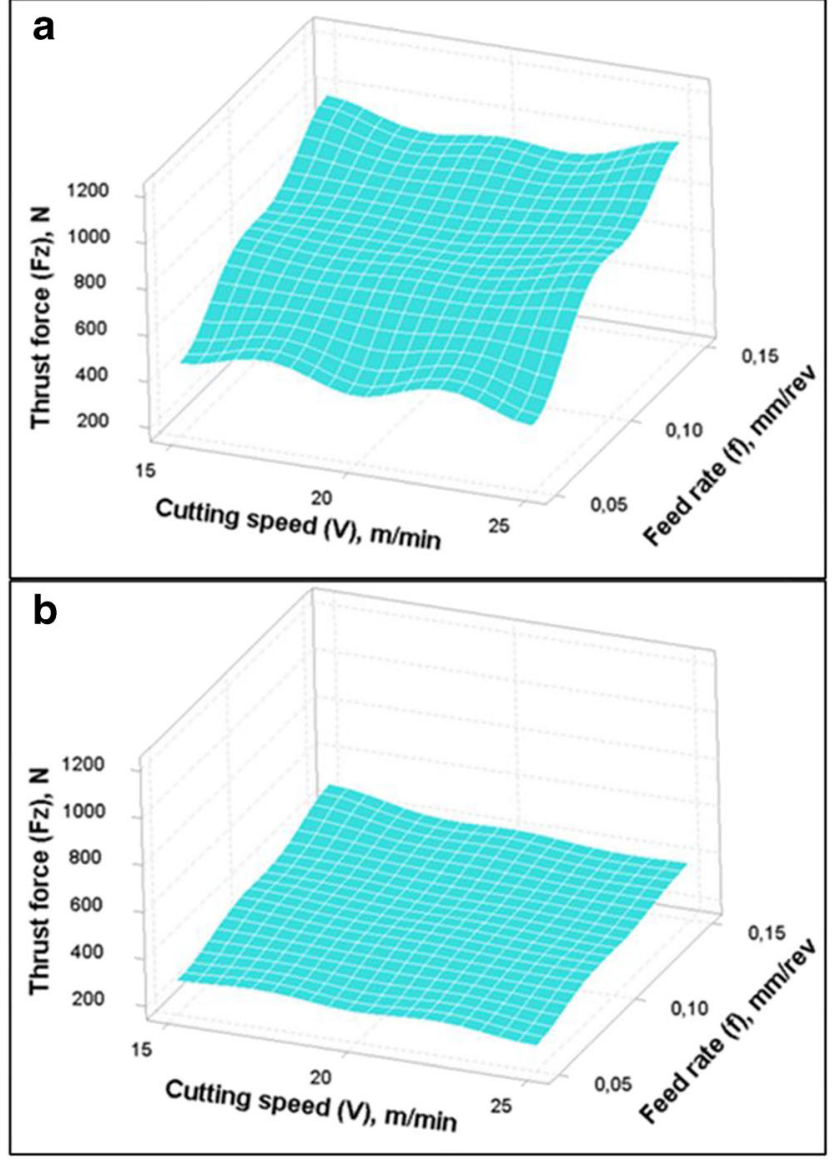

Fig. 9 Thrust force (Fz) assessment. a Uncoated HSS. b PVD-coated HSS

appreciated that the negativities such as the fact that the drilling process is performed in a closed area and the chip evacuation becomes difficult due to the increased chip volume may be effective on this situation [44].

In all variables of cutting speed (15-25 $\mathrm{m} / \mathrm{min})$, depending on the increase in the feed rate, there is a rise in $\mathrm{Fz}$ values for both cutting tools. The volume of chip removed can be explained with the increase in Fz and feed rate [45-50]. For each cutting speed, it has been calculated by an average of $74.6 \%$ and $30 \%$ for uncoated and coated cutting inserts by increasing the feed rate from $0.05 \mathrm{~mm} / \mathrm{rev}$ by $100 \%$. This increase was obtained by $200 \%$ of the feed rate for the same variables and $121.3 \%$ and $57.3 \%$, respectively. In the light of all these results, it is conceivable to tell that the feed rate is more effective on the modification of Fz than the cutting speed. From the plotted graphs, it is clear that the outcomes obtained with coated cutting tools are lower than the uncoated cutting tools. When the Fz results were evaluated with regard to all speedfeed combinations, an average of $49.6 \%$ lower results were obtained for coated tools in comparison with uncoated tools. The lowest Fz value was obtained as $248 \mathrm{~N}$ at $0.05 \mathrm{~mm} / \mathrm{rev}$ feed rate and $25 \mathrm{~m} / \mathrm{min}$ cutting speed. Result attained for uncoated tools with the same parameters is $425 \mathrm{~N}$. It can be explained by the fact that the changes obtained with coated cutting tools are better on the machining output than uncoated cutting tools in terms of efficiency, and this situation can be explained by the low friction coefficient of coated cutting tools and the effect of reducing the thrust forces by reducing the friction at the tool-chip junction [50-53]. Considering the energy consumption effects on costs, it can be said that coated cutting tools can be preferred over uncoated tools as they will be more efficient.

A statistical method, i.e., analysis of variance, was employed to determine the effect of tool coating, speed-feed combination on $\mathrm{Fz}$ and $\mathrm{Ra}$. This analysis was performed at the 95\% confidence level. ANOVA results for Fz are presented in Table 6. To communicate the impact of control factors on output statistically, the $F$ values are taken into account in deciding the significance level $(P)$ and the contribution rate. For the control factors to be statistically significant on the output, the $P$ value must be less than 0.05 , and the control factor with high $F$ value is acknowledged in determining the factor that affects the most $[54,55]$. The effects of the drilling parameters in the study on the Fz are displayed as percentage contribution ratio (PCR) in Table 6.
Table 6 ANOVA results for thrust force (Fz)

\begin{tabular}{lllllll}
\hline Source & Degree of freedom & Sum of square & Mean square & $F$ & $P$ & PCR (\%) \\
\hline$C$ & 1 & 641467 & 641467 & 513.420 & 0.000 & 56.53 \\
$V$ & 1 & 705 & 705 & 0.560 & 0.472 & 0.06 \\
$f$ & 1 & 354320 & 354320 & 283.590 & 0.000 & 31.22 \\
$C^{*} C$ & 1 & 6834 & 6834 & 4.350 & 0.061 & 0.60 \\
$V^{*} V$ & 1 & 3062 & 3062 & 2.450 & 0.152 & 0.27 \\
$f^{*} f$ & 1 & 4312 & 4312 & 3.450 & 0.096 & 0.38 \\
$C^{*} V$ & 1 & 6440 & 6440 & 5.150 & 0.049 & 0.57 \\
$C^{*} f$ & 1 & 106408 & 106408 & 85.170 & 0.000 & 9.38 \\
$V^{*} f$ & 1 & 8 & 8 & 0.010 & 0.938 & 0.00 \\
Error & 9 & 11245 & 1249 & & & 0.99 \\
Total & 17 & 1134801 & & & & 100.000
\end{tabular}




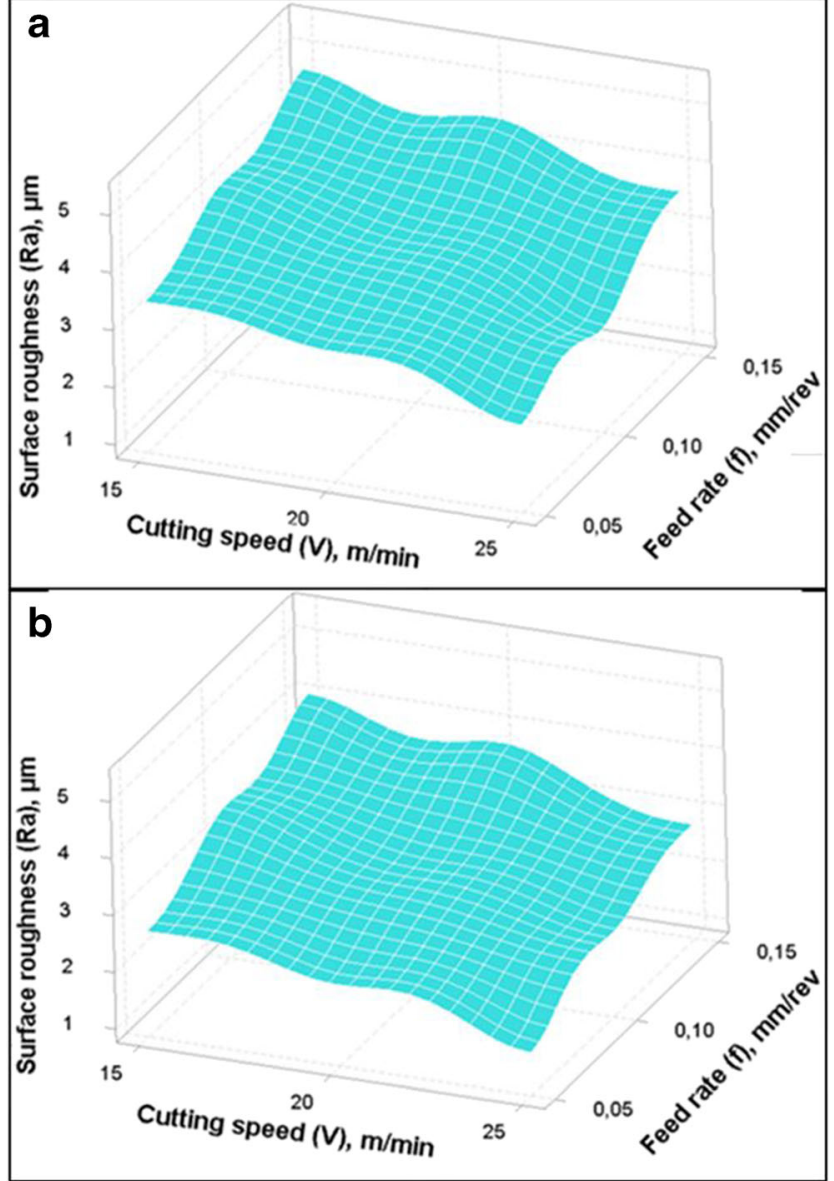

Fig. 10 Surface roughness (Ra) assessment. a Uncoated HSS. b PVDcoated HSS

According to Table 6, the utmost dominant factor on the Fz was the coating condition with $56.53 \%$ PCR followed by coating condition with $31.22 \%$ and $9.38 \%$ additive rates, respectively; the feed rate and coating condition * feed rate followed the interaction.

\subsubsection{Assessment of surface roughness and chip formation}

The changes in surface roughness obtained as an outcome of drilling with uncoated and PVD-coated drills are given in Fig. 10.

With increasing cutting speeds, the quality of the surface improved. This may be attributed to decreasing friction due to the decreasing of the material yield strength [56-60] by the temperature increase by increasing speed [61,62]. When the Ra value is examined in the given graphics; in all variables of the feed rate $(0.05-0.15 \mathrm{~mm} / \mathrm{rev})$, there is a reduction in $\mathrm{Ra}$ as a reason of increasing in cutting speed. In all values of the feed, the rise in cutting speed is observed to decrease the surface roughness by $10.6 \%$ and $15.2 \%$ on average for uncoated and coated tools, respectively. In the rise of cutting speed from 15 to $25 \mathrm{~m} / \mathrm{min}$, Ra change was obtained as $19.8 \%$ and $36.6 \%$, respectively.

According to the results of ANOVA accomplished at 95\% confidence level, the effects of drilling parameters on Ra are displayed in Table 7.

According to Table 7, the effective factor on Ra was feed rate of PCR with $43.62 \%$. The feed rate with the contribution rates of $36.75 \%$ and $17.02 \%$, respectively, followed by cutting speed and coating condition.

Surface and chip images at increasing cutting speed variables are given in Fig. 11. There are no observable changes in the chip samples taken with the rise in cutting speed. It is visible that at high speed, burnt chips were formed as a result of more heat.

The volume of chip removed with the increase in feed rate, resist chip breaking, causes to increase the $\mathrm{Fz}$ [63] and indirectly the cutting temperature [64]. Reliant to cutting speed variables (15-25 $\mathrm{m} / \mathrm{min})$, the Ra rises with the increase in feed rate. It is understood from the plots that the mechanical loads that increase on the cutting tool negatively affect the surface quality [65]. In all cutting speed variables, from an increase of $100 \%(0.05-0.1 \mathrm{~mm} / \mathrm{rev})$, an average increase of $14.5 \%$ and $35.1 \%$ was obtained for uncoated and coated tools,
Table 7 ANOVA results for surface roughness (Ra)

\begin{tabular}{lllllll}
\hline Source & Degree of freedom & Sum of square & Mean square & $F$ & $P$ & PCR (\%) \\
\hline$C$ & 1 & 2.1291 & 2.12913 & 104.46 & 0.000 & 17.02 \\
$V$ & 1 & 4.599 & 4.59896 & 225.63 & 0.000 & 36.75 \\
$f$ & 1 & 5.4586 & 5.45862 & 267.81 & 0.000 & 43.62 \\
$C^{*} C$ & 1 & 0.0133 & 0.0133 & 0.65 & 0.564 & 0.11 \\
$V^{*} V$ & 1 & 0.0929 & 0.09291 & 4.56 & 0.062 & 0.74 \\
$f^{*} f$ & 1 & 0.0265 & 0.02646 & 1.3 & 0.284 & 0.21 \\
$C^{*} V$ & 1 & 0.0022 & 0.00217 & 0.11 & 0.752 & 0.02 \\
$C^{*} f$ & 1 & 0.0053 & 0.00532 & 0.26 & 0.622 & 0.04 \\
$V^{*} f$ & 1 & 0.0027 & 0.00272 & 0.13 & 0.723 & 0.02 \\
Error & 9 & 0.1834 & 0.02038 & & & 1.47 \\
Total & 17 & 12.513 & & & & 100.00 \\
\hline
\end{tabular}




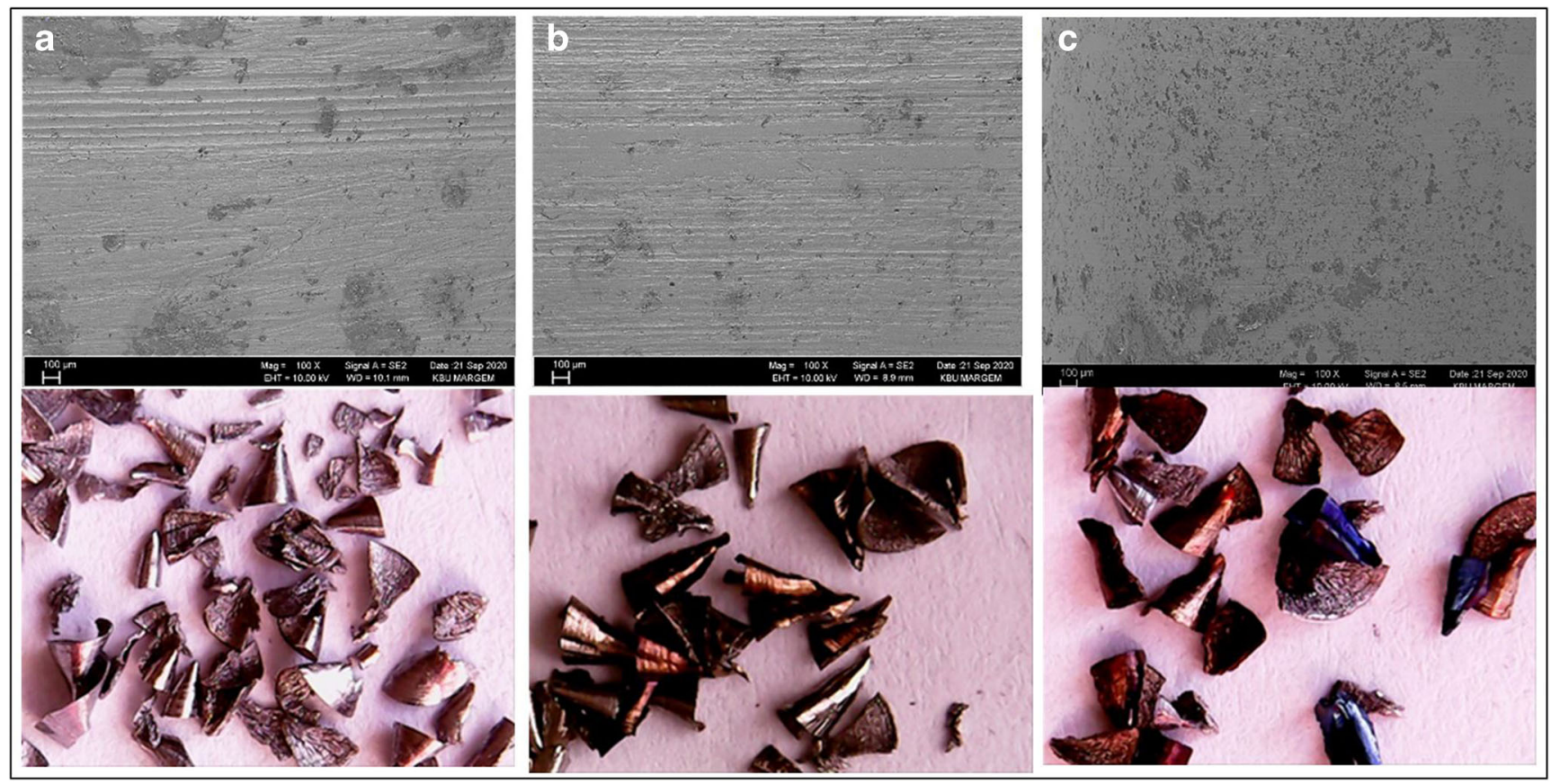

Fig. 11 Surface and chip images at $0.1 \mathrm{~mm} / \mathrm{rev}$ with uncoated cutting tool. a $V: 15 \mathrm{~m} / \mathrm{min}$. b $V: 20 \mathrm{~m} / \mathrm{min}$. c $V: 25 \mathrm{~m} / \mathrm{min}$

respectively. In the increase (200\%) of the feed rate from 0.05 to $0.15 \mathrm{~mm} / \mathrm{ev}$, Ra changes by $46.2 \%$ and $67.6 \%$, respectively. For coated cutting tools, it is possible to say that it is effective on $\mathrm{Ra}$ as well as on Fz values. Surface and chip images depending on the rise in feed rate are given in Fig. 12. Furthermore, the chip formation becomes irregular and interrupted at higher feed rate. This phenomenon explains the reason for the increase on Ra.
Lowest Ra value for the coated tool was found as $1.51 \mu \mathrm{m}$ at $25 \mathrm{~m} / \mathrm{min}$ cutting speed and $0.05 \mathrm{~mm} / \mathrm{rev}$ feed rate. The result obtained with the uncoated cutting tool was measured as $2.27 \mu \mathrm{m}$. When the Ra measurements are inspected according to all cutting parameters, the results obtained with coated cutting tools are on average $20.4 \%$ lower than the uncoated tools. The surface images obtained with both sets in these parameters are given in Fig. 13. In addition, the highest Ra

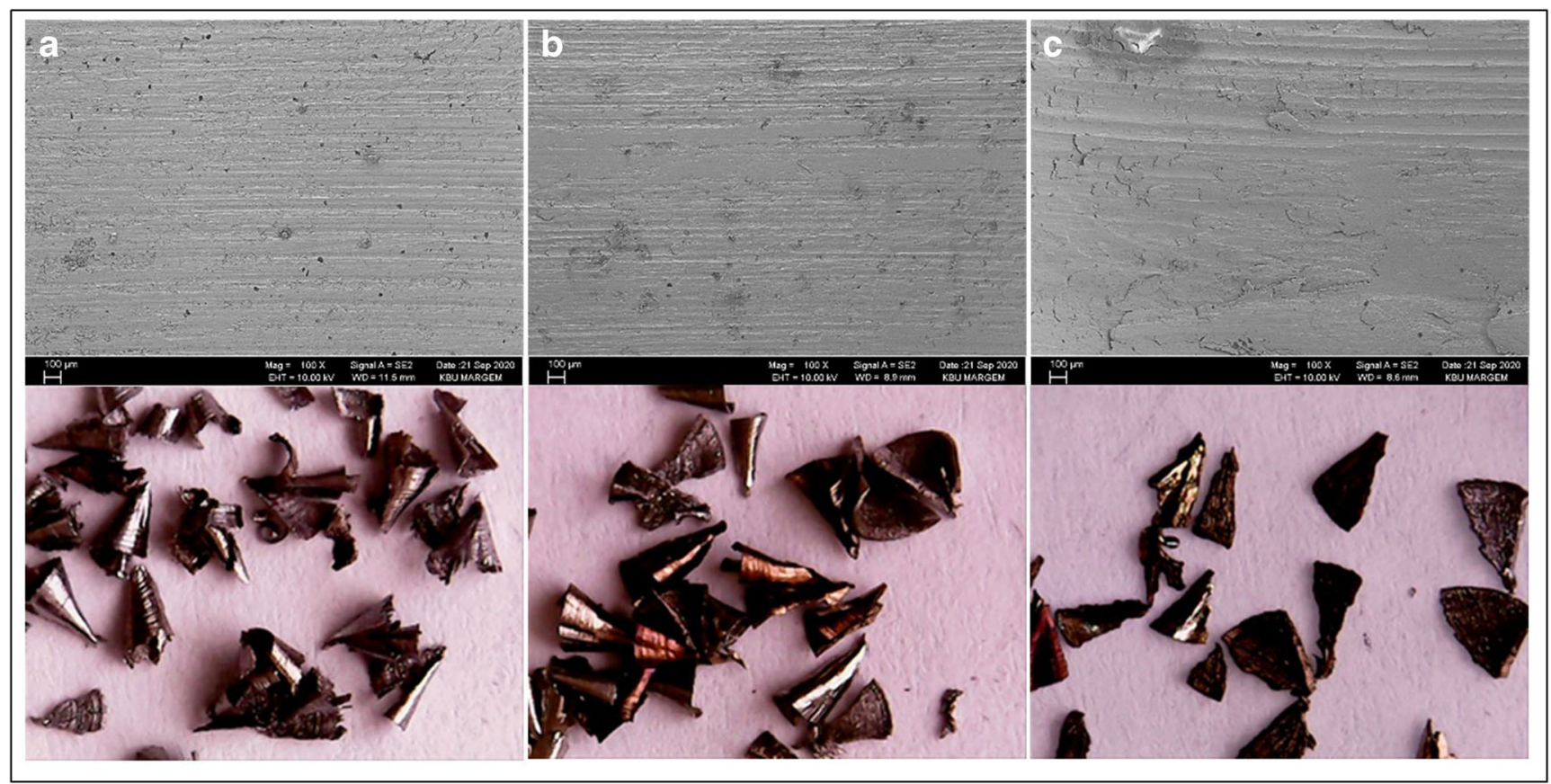

Fig. 12 Surface and chip images at $20 \mathrm{~m} / \mathrm{min}$ with uncoated cutting tool. a $f: 0.05 \mathrm{~mm} / \mathrm{rev}$. b $0.1 \mathrm{~mm} / \mathrm{rev}$. c $0.15 \mathrm{~mm} / \mathrm{rev}$ 
Fig. 13 SEM images for lowest Ra. a Uncoated HSS. b PVDcoated HSS
Fig. 14 SEM images of the highest Ra. a Uncoated HSS. b PVD-coated HSS
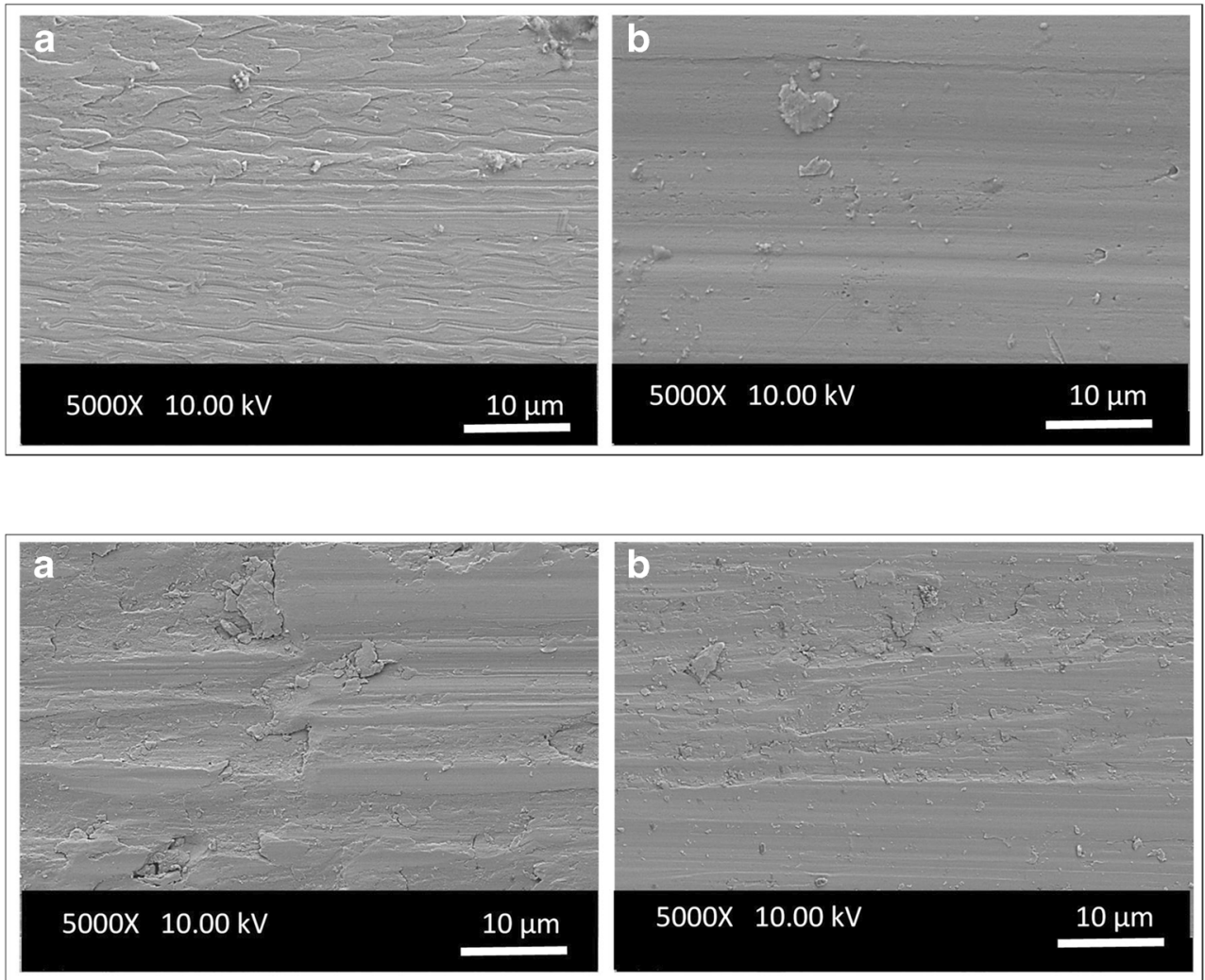

value was attained at the lowest cutting speed $(15 \mathrm{~m} / \mathrm{min})$ and the highest feed rate $(0.15 \mathrm{~mm} / \mathrm{rev})$ as 4.68 and $4.03 \mu \mathrm{m}$ for uncoated and coated tools, respectively (Fig. 14). Moreover, the chip images obtained with uncoated and coated cutting tools are given in Fig. 15. The chips obtained with coated cutting tools are in the form of a more regular and smaller step helical chip form. This fact explains the better surface quality achieved with coated tools. Considering that it is one of the most vital criteria used in estimating the machinability of the material, it is possible to claim that coated cutting tools can be preferred over uncoated tools in terms of machined surface quality.

\section{Conclusions}

This investigation consists of the formation of a new type steel in the ideal structure was made by adding various extents of molybdenum powder into Fe powders. Tensile test and hardness test were applied to alloy steel samples with different chemical compositions to determine the strain, stress, and hardness values. Furthermore, the machinability properties of $3 \%$ Mo-added steel having the highest mechanical properties among the other manufactured samples were examined. The important results that are obtained from the study are summarized below.
Fig. 15 Chip images $(V: 15$ $\mathrm{m} / \mathrm{min}, f: 0.05 \mathrm{~mm} / \mathrm{rev})$. a Uncoated HSS. b PVD-coated HSS

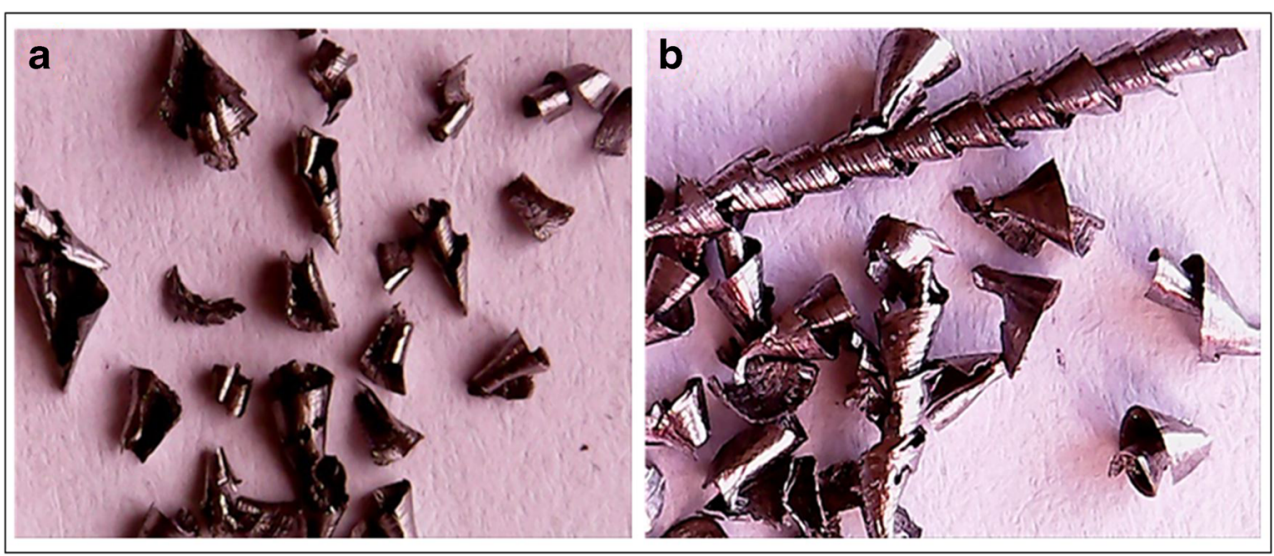


- Perlite ratio of powder metal steel with $\mathrm{Fe}-\mathrm{C}$ composition sintered at $1400{ }^{\circ} \mathrm{C}$ increased with the addition of alloying element. At the same time, the perlite ratio increased while the ferrite ratio decreased.

- Generally, it has been observed that the tensile and yield strength increases, and the percent elongation decreases with the increase in the amount of molybdenum up to a certain level. The reason for the rise in strength is attributed to the increase of perlite amount of nickel in the microstructure and also to the bainite and martensite phases formed in the structure.

- EDS analysis of PM steels reveals that Mo, C, and N elements and precipitates such as $\mathrm{CrC}(\mathrm{N})$ and $\mathrm{MoC}(\mathrm{N})$ formed by these elements are in the iron matrix.

- It has been observed that steels with alloying element added have superior mechanical properties compared to PM steels that are not added. The reason for this is presumed to be related to the strong carbide builder of alloying elements or to transform the microstructure into a harder phase. Refining of grain size and precipitation hardening during sintering or cooling after sintering increase the strength of steel.

- For each cutting speed, the increase of thrust force was calculated by an average of $74.6 \%$ and $30 \%$ for uncoated and coated cutting inserts, respectively, by increasing the feed rate from 0.05 to $0.1 \mathrm{~mm} / \mathrm{rev}$.

- In the increase of cutting speed from 15 to $25 \mathrm{~m} / \mathrm{min}$, decrease of Ra was obtained as $19.8 \%$ and $36.6 \%$, respectively.

- The most important factors on the Fz and Ra are the coating condition and the feed rate with $56.53 \%$ and $43.62 \%$ PCR, respectively.

- The chip shape becomes erratic due to the increase in the feed rate and it is evident that the form of the chip is disrupted while no observable change with the rise in speed. The explanation for the increase of Ra is clarified by this circumstance.

Author contribution Conceptualization: M.A.E, B.A., M.M.; methodology: M.A.E, N.Y, M.E.K; investigation: M.A.E, N.Y, M.E.K; resources: M.A.E, N.Y, M.E.K, B.A., and M.M.; writing (original draft preparation): M.A.E, N.Y, M.E.K, B.A., M.M., and N.S.R.; writing-review and editing: N.Y, M.E.K, M.M., and N.S.R.; visualization: N.Y, M.E.K, M.M., and N.S.R.; supervision: M.A.E, N.Y., M.M.; project administration: M.A.E.

Funding This work was financially supported by the Scientific Research Projects Coordination Unit of Karabük University (Karabük, Turkey). Project Number: KBÜ-BAP18YL-017.

Data availability Not applicable

\section{Declarations}

Ethics approval and consent to participate Not applicable
Consent for publication The consent to submit this paper has been received explicitly from all co-authors.

Competing interests The authors declare no competing interests.

Open Access This article is licensed under a Creative Commons Attribution 4.0 International License, which permits use, sharing, adaptation, distribution and reproduction in any medium or format, as long as you give appropriate credit to the original author(s) and the source, provide a link to the Creative Commons licence, and indicate if changes were made. The images or other third party material in this article are included in the article's Creative Commons licence, unless indicated otherwise in a credit line to the material. If material is not included in the article's Creative Commons licence and your intended use is not permitted by statutory regulation or exceeds the permitted use, you will need to obtain permission directly from the copyright holder. To view a copy of this licence, visit http://creativecommons.org/licenses/by/4.0/.

\section{References}

1. Türkmen M, Karabulut H, Erden MA, Gündüz S (2017) Effect of tin addition on the microstructure and mechanical properties of $\mathrm{Pm}$ steels. e-Jour New World Sci Acad 12:178-184. https://doi.org/10. 12739/nwsa.2017.12.4.2a0125

2. Erden MA (2016) Investigation of the effect of nickel content on microstructure and mechanical properties of non alloyed steels producted by powder metallurgy. GU J Sci PartC 4:241-245

3. Demir H, Gündüz S, Erden MA (2018) Influence of the heat treatment on the microstructure and machinability of AISI H13 hot work tool steel. Int J Adv Manuf Technol 95:2951-2958. https://doi.org/ 10.1007/s00170-017-1426-3

4. Erden MA, Gündüz S, Çalıülü U, Boz M (2018) Investıgation of hardness and microstructure properties of non alloyed and hardox steel combined with submerged arc welding method. J Fac Eng Archit Gazi Univ 33:221-226. https://doi.org/10.17341/ gazimmfd.406794

5. Özdemirler D, Gündüz S, Erden M (2017) Influence of nbc addition on the sintering behaviour of medium carbon PM steels. Metals (Basel) 7:121. https://doi.org/10.3390/met7040121

6. Gündüz S, Karabulut H, Erden MA, Türkmen M (2013) Microstructural effects on fatigue behaviour of a forged medium carbon microalloyed steel. Mater Test 55:865-870. https://doi.org/ $10.3139 / 120.110511$

7. Rathore SS, Salve MM, Dabhade VV (2015) Effect of molybdenum addition on the mechanical properties of sinter-forged $\mathrm{Fe}-\mathrm{Cu}-$ C alloys. J Alloys Compd 649:988-995. https://doi.org/10.1016/j. jallcom.2015.07.156

8. Gladman T, Woodhead JH (1960) The accuracy of point counting in metallographic investigations. J Iron Steel Inst 194

9. Hossam H (2013) Thermodynamic calculation for silicon modified AISI M2 high speed tool steel. J Miner Mater Charact Eng 1:257270

10. Lee WB, Hong SG, Park CG, Kim KH, Park SH (2000) Influence of Mo on precipitation hardening in hot rolled HSLA steels containing Nb. Scr Mater 43:319-324. https://doi.org/10.1016/S13596462(00)00411-5

11. Junhua K, Lin Z, Bin G, Pinghe L, Aihua W, Changsheng X (2004) Influence of Mo content on microstructure and mechanical properties of high strength pipeline steel. Mater Des 25:723-728. https:// doi.org/10.1016/j.matdes.2004.03.009

12. Karabulut H, Türkmen M (2017) Effect of the amount of Si and aging durations in Al2024-Si alloyed composites produced by 
powder metallurgy method. Omer Halisdemir Univ J Eng Sci 6: 226-231

13. Simsir H, Akgul Y, Erden MA (2020) Hydrothermal carbon effect on iron matrix composites produced by powder metallurgy. Mater Chem Phys 242:122557. https://doi.org/10.1016/j.matchemphys. 2019.122557

14. Erden MA, Ayvac1 B (2020) The effect on mechanical properties of pressing technique in PM steels. Acta Phys Pol A 135:1078-1080. https://doi.org/10.12693/APhysPolA.135.1078

15. Türkmen M, Erden MA, Karabulut H, Gündüz S (2019) The effects of heat treatment on the microstructure and mechanical properties of $\mathrm{Nb}-\mathrm{V}$ microalloyed powder metallurgy steels. Acta Phys Pol A 135:834-836. https://doi.org/10.12693/APhysPolA.135.834

16. Erden MA, Taşçi MT (2016) The effect of Ni on the microstructure and mechanical properties of $\mathrm{Nb}-\mathrm{V}$ microalloyed steels produced by powder metallurgy. J Polytech 19:611-616

17. Gunduz S, Erden MA, Karabulut H, Turkmen M (2016) The effect of vanadium and titanium on mechanical properties of microalloyed PM steel. Powder Metall Met Ceram 55:277-287. https://doi.org/ 10.1007/s11106-016-9803-2

18. M'Saoubi R, Czotscher T, Andersson O, Meyer D (2014) Machinability of powder metallurgy steels using PcBN inserts. Procedia CIRP 14:83-88. https://doi.org/10.1016/j.procir.2014. 03.094

19. Kulkarni H, Dabhade VV (2019) Green machining of powdermetallurgy-steels (PMS): an overview. J Manuf Process 44:1-18. https://doi.org/10.1016/j.jmapro.2019.05.009

20. Robert-Perron E, Blais C, Pelletier S, Thomas Y (2007) Machinability of green powder metallurgy components: Part I. characterization of the influence of tool wear. Metall Mater Trans A Phys Metall Mater Sci 38:1330-1336. https://doi.org/10.1007/ s11661-007-9191-9

21. Robert-Perron E, Blais C, Pelletier S, Thomas Y (2007) Drilling of high quality features in green powder metallurgy components. Mater Sci Eng A 458:195-201. https://doi.org/10.1016/j.msea. 2006.12.050

22. Baran MC, Graham AH, Davala AB et al (1999) A superior sinterhardenable material. Adv Powder Metall Part Mater 2:185

23. Wang X, Yang L, Qiao Y, Guo P, Wang S (2018) Cutting characteristics and surface integrity in drilling of powder metallurgy nickel-based superalloy FGH97. Procedia CIRP 71:370-373. https://doi.org/10.1016/j.procir.2018.05.043

24. Hayajneh MT, Hassan AM, Mayyas AT (2009) Artificial neural network modeling of the drilling process of self-lubricated aluminum/alumina/graphite hybrid composites synthesized by powder metallurgy technique. J Alloys Compd 478:559-565. https://doi. org/10.1016/j.jallcom.2008.11.155

25. Czampa M, Markos S, Szalay T (2013) Improvement of drilling possibilities for machining powder metallurgy materials. Procedia CIRP 7:288-293. https://doi.org/10.1016/j.procir.2013.05.049

26. Robert-Perron E, Blais C, Thomas Y, Pelletier S, Dionne M (2005) An integrated approach to the characterization of powder metallurgy components performance during green machining. Mater Sci Eng A 402:325-334. https://doi.org/10.1016/j.msea.2005.05.019

27. Narayanasamy R, Anandakrishnan V, Pandey KS (2009) Effect of molybdenum addition on workability of powder metallurgy steels during cold upsetting. Mater Sci Eng A 517:30-36. https://doi.org/ 10.1016/j.msea.2009.03.036

28. Robert M (1984) Powder metallurgy science. Metal Powder Industry Federation, New jersey

29. Korkmaz ME, Günay M, Verleysen P (2019) Investigation of tensile Johnson-Cook model parameters for Nimonic 80A superalloy. J Alloys Compd 801:542-549. https://doi.org/10.1016/J. JALLCOM.2019.06.153

30. Kostryzhev AG, Al Shahrani A, Zhu C et al (2014) Effect of niobium clustering and precipitation on strength of an NbTi- microalloyed ferritic steel. Mater Sci Eng A 607:226-235. https:// doi.org/10.1016/j.msea.2014.03.140

31. Uygur İ, Gerengi H, Erden MA, Yildız M (2017) The effect of niobium and vanadium on corrosion of low carbon steel obtained by powder metallurgy in $3.5 \% \mathrm{NaCl}$ environment. Technol Appl Sci 12:73-86

32. Nie Z, Wang G, Yu J, Liu D, Rong Y(K) (2016) Phase-based constitutive modeling and experimental study for dynamic mechanical behavior of martensitic stainless steel under high strain rate in a thermal cycle. Mech Mater 101:160-169. https://doi.org/10.1016/j. mechmat.2016.08.003

33. Du P, Wang G, Nie Z, Rong Y (2014) A FEM-based inverse calculation method for determination of heat transfer coefficient in liquid quenching process. In: TMS 2014:143rd Annual Meeting \& Exhibition. Springer International Publishing, Cham, pp 309 315

34. Nie Z, Wang G, Yu J, Rong YK (2016) Dynamic mechanical behavior and phase-based constitutive model of 20Cr12Ni4Mo3VNiN in austenitizing stage BT - TMS 2014: 143rd Annual Meeting \& Exhibition. In: TMS 2014: 143rd Annual Meeting \& Exhibition. Springer International Publishing, Cham, pp 1125-1131

35. Erden MA (2017) The effect of the sintering temperature and addition of niobium and vanadium on the microstructure and mechanical properties of microalloyed PM steels. Metals (Basel):7. https:// doi.org/10.3390/met7090329

36. Erden MA (2016) Effect of $\mathrm{C}$ content on microstructure and mechanical properties of powder metallurgy steels. Powder Metall Met Ceram 55:164-171. https://doi.org/10.1007/s11106-016-9791-2

37. Shanmugasundaram D, Chandramouli R (2009) Tensile and impact behaviour of sinter-forged $\mathrm{Cr}, \mathrm{Ni}$ and $\mathrm{Mo}$ alloyed powder metallurgy steels. Mater Des 30:3444-3449. https://doi.org/10.1016/j. matdes.2009.03.020

38. Khan AM, He N, Jamil M, Raza SM (2021) Energy characterization and energy-saving strategies in sustainable machining processes: a state-of-the-art review. J Prod Syst Manuf Sci 2:26-49

39. Zaman PB, Sultana N, Dhar NR (2020) Quantifying the effects of cooling condition, tool type and cutting parameters on machinability of turning AISI 4140 steel using full factorial DOE. J Prod Syst Manuf Sci 1:1-24

40. Sofuoğlu MA, Gürgen S, Kuşhan MC (2020) Experimental investigation of newly designed cutting tool inserts in turning. J Prod Syst Manuf Sci 1:1-24

41. Yaşar N (2019) Thrust force modelling and surface roughness optimization in drilling of AA-7075: FEM and GRA. J Mech Sci Technol 33:4771-4781. https://doi.org/10.1007/s12206-019-0918-5

42. Ni C, Zhu L, Zheng Z, Zhang J, Yang Y, Yang J, Bai Y, Weng C, Lu WF, Wang H (2020) Effect of material anisotropy on ultraprecision machining of Ti-6Al-4V alloy fabricated by selective laser melting. J Alloys Compd 848:156457. https://doi.org/10.1016/j. jallcom.2020.156457

43. Yildiz Y, Gunay M, Seker U (2007) The effect of the cutting fluid on surface roughness in boring of low carbon steel. Mach Sci Technol 11:553-560. https://doi.org/10.1080/10910340701697052

44. Suresh Kumar Reddy N, Venkateswara Rao P (2006) Experimental investigation to study the effect of solid lubricants on cutting forces and surface quality in end milling. Int J Mach Tools Manuf 46:189 198. https://doi.org/10.1016/j.ijmachtools.2005.04.008

45. Paulo Davim J (2008) Machining. In: Fundamentals and recent advances

46. Yaşar N, Günay M (2019) Experimental investigation on novel drilling strategy of CFRP laminates using variable feed rate. J Braz Soc Mech Sci Eng 41:150. https://doi.org/10.1007/s40430019-1658-2

47. Korkmaz ME (2020) Verification of Johnson-Cook parameters of ferritic stainless steel by drilling process: experimental and finite 
element simulations. J Mater Res Technol 9:6322-6330. https://doi. org/10.1016/j.jmrt.2020.03.045

48. Meral G, Sarkaya M, Mia M, Dilipak H, Şeker U, Gupta MK (2019) Multi-objective optimization of surface roughness, thrust force, and torque produced by novel drill geometries using Taguchi-based GRA. Int J Adv Manuf Technol 101:1595-1610. https://doi.org/10.1007/s00170-018-3061-z

49. Yaşar N, Korkmaz ME, Günay M (2017) Investigation on hole quality of cutting conditions in drilling of CFRP composite. In: Investigation on hole quality of cutting conditions in drilling of CFRP composite. MATEC Web of Conferences, In

50. Kara F, Karabatak M, Ayyıldız M, Nas E (2020) Effect of machinability, microstructure and hardness of deep cryogenic treatment in hard turning of AISI D2 steel with ceramic cutting. J Mater Res Technol 9:969-983. https://doi.org/10.1016/j.jmrt.2019.11.037

51. Braic V, Zoita CN, Balaceanu M, Kiss A, Vladescu A, Popescu A, Braic M (2010) TiAlN/TiAlZrN multilayered hard coatings for enhanced performance of HSS drilling tools. Surf Coat Technol 204: 1925-1928. https://doi.org/10.1016/j.surfcoat.2009.08.011

52. Maranhão C, Paulo Davim J (2010) Finite element modelling of machining of AISI 316 steel: numerical simulation and experimental validation. Simul Model Pract Theory 18:139-156. https://doi. org/10.1016/J.SIMPAT.2009.10.001

53. Gok K (2015) Development of three-dimensional finite element model to calculate the turning processing parameters in turning operations. Measurement 75:57-68. https://doi.org/10.1016/J. MEASUREMENT.2015.07.034

54. Yurtkuran H, Korkmaz ME, Günay M (2016) Modelling and optimization of the surface roughness in high speed hard turning with coated and uncoated CBN insert. Gazi Univ J Sci 29:

55. Korkmaz ME, Günay M (2018) Experimental and statistical analysis on machinability of Nimonic80A superalloy with PVD coated carbide. Sigma J Eng Nat Sci 36:1141-1152

56. Trent EM (1989) Metal cutting. Butterworths Press, London

57. Singh D, Rao PV (2007) A surface roughness prediction model for hard turning process. Int J Adv Manuf Technol 32:1115-1124. https://doi.org/10.1007/s00170-006-0429-2
58. Günay M, Korkmaz ME, Yaşar N (2020) Performance analysis of coated carbide tool in turning of Nimonic 80A superalloy under different cutting environments. J Manuf Process 56:678-687. https://doi.org/10.1016/j.jmapro.2020.05.031

59. Kara F, Takmaz A (2019) Optimization of cryogenic treatment effects on the surface roughness of cutting tools. Mater Test 61: 1101-1104. https://doi.org/10.3139/120.111427

60. Kara F, Aslantaș K, Çiçek A (2016) Prediction of cutting temperature in orthogonal machining of AISI 316L using artificial neural network. Appl Soft Comput 38:64-74. https://doi.org/10.1016/j. asoc.2015.09.034

61. Nie Z, Wang G, Jiang F, Lin YL, Rong YM (2018) Investigation of modeling on single grit grinding for martensitic stainless steel. $\mathrm{J}$ Cent South Univ 25:1862-1869. https://doi.org/10.1007/s11771018-3875-8

62. Nie Z, Wang G, Wang L, Rong YK (2019) A coupled thermomechanical modeling method for predicting grinding residual stress based on randomly distributed abrasive grains. J Manuf Sci Eng Trans ASME 141:1-12. https://doi.org/10.1115/1. 4043799

63. Günay M, Meral T, Korkmaz ME (2018) Drillability analysis of AISI 420 martensitic stainless steel by finite element method. Gazi J Eng Sci 4:223-229

64. Jamil M, Khan AM, Mia M, Iqbal A, Gupta MK, Sen B (2019) Evaluating the effect of micro-lubrication in orthopedic drilling. Proc Inst Mech Eng Part H J Eng Med 233:1024-1041. https:// doi.org/10.1177/0954411919865389

65. Fnides B, Aouici H, Yallese MA (2008) Cutting forces and surface roughness in hard turning of hot work steel X38CrMoV5-1 using mixed ceramic. Mechanika 70:73-77. https://doi.org/10.5755/j01. mech.70.2.14941

Publisher's note Springer Nature remains neutral with regard to jurisdictional claims in published maps and institutional affiliations. 